\title{
Komodifikasi Upacara Tradisional Seren Taun dalam Pembentukan Identitas Komunitas
}

\author{
Co-modification of Seren Taun Traditional Ceremony on Community Identity Formation
}

\author{
Untung Prasetyo*) dan Sarwititi Sarwoprasodjo \\ Departemen Sains Komunikasi dan Pengembangan Masyarakat, Fakultas Ekologi Manusia, IPB \\ *) E-mail : u_prasetyo@yahoo.com
}

Diterima 16 Februari 2011/Disetujui 24 Mei 2011

\begin{abstract}
This study is focused on the correlation of commodification the Seren Taun traditional ceremony within the form a community identity of Kampung Budaya Sindangbarang. The objective of the study was to determine 1) to what extent is the correlation between commodification the Seren Taun traditional ceremony and its motive of to implement the Seren Taun traditional ceremony, and 2) to what extent is the correlation between motive of to implement the Seren Taun traditional ceremony and its behavior of to implement of the Seren Taun traditional ceremony within the form a community identity of Kampung Budaya Sindangbarang. The reaserch showed that commodification the Seren Taun traditional ceremony was related to the form a community identity of Kampung Budaya Sindangbarang. The lower was commodification the Seren Taun traditional ceremony, then the higher was the form a community identity of Kampung Budaya Sindangbarang.The reaserch explained that community of Kampung Budaya Sindangbarang is consistent to look the Seren Taun traditional ceremony as their facility to describe about thanks be to God, to construction a community solidarity, to keep a community institutional, and to keep Sunda traditional art.
\end{abstract}

Keywords : commodification, traditional ceremony, community identity

\section{PENDAHULUAN}

\section{Latar Belakang}

Kebudayaan sebagai identitas komunitas bukan hanya dipahami sebagai pembeda dengan komunitas lain, melainkan sebagai suatu hal yang dapat digunakan untuk mengenal kehidupan komunitas, cara-cara komunitas menyusun pengetahuan, menampilkan perasaan, dan cara mereka bertindak. Peranan kebudayaan menjadi sangat besar dalam ekosistem komunikasi, karena karakteristik kebudayaan antar komunitas dapat membedakan kebudayaan lisan dan tertulis yang merupakan kebiasaan suatu komunitas dalam mengkomunikasikan identitasnya. Hal tersebut senada dengan pemikiran Taylor (Ritzer dan Goodman, 2008), bahwa kebudayaan dapat diartikan sebagai pandangan hidup dari sebuah komunitas atau kelompok. Aspek kebudayaan sebagai bagian dari pembangunan nasional bukan saja dinilai seberapa banyak penghargaan lencana kebudayaan dan pameran unsur kebudayaan, melainkan mengakui eksistensi serta mengakomodasi kepentingan setiap komunitas dan budaya lokal dalam kehidupan berbangsa.

Aspek-aspek budaya yang masih bertahan dan hidup dalam komunitas ditampilkan melalui kegiatan upacara tradisional yang masih banyak dilaksanakan oleh komunitas tersebut. Upacara tersebut berfungsi antara lain sebagai sarana untuk mentransfer nilai-nilai dari satu generasi ke generasi berikutnya. Selain itu, upacara tradisional juga berfungsi sebagai pengokoh normanorma dan nilai-nilai budaya yang telah berlaku secara turun-temurun.

Norma dan nilai budaya ditampilkan melalui peragaan secara simbolis dalam bentuk upacara. Bagi masyarakat pendukungnya, upacara merupakan bagian integral, akrab, serta komunikatif dalam kehidupan kulturalnya. Upacara yang sarat dengan simbol-simbol yang mengandung makna-makna tertentu, merupakan suatu cara yang menginternalisasikan dan mensosialisasikan nilai-nilai kepada masyarakat. Oleh karena itu, upacara bukan hanya menampilkan materi dan tahapan-tahapan upacara, juga terkandung ungkapan-ungkapan emosional yang merangsang terciptanya kekukuhan norma dan nilai yang kohesif diantara warga masyarakat.

Upacara tradisional sebagai salah satu unsur kebudayaan yang dimiliki oleh komunitas merupakan unsur yang dapat menggambarkan sejauh mana komunitas menjaga eksistensi identitasnya. Hal ini dapat dijelaskan bahwa dalam upacara tradisional dimungkinkan akan terlihat seluruh anggota komunitas ikut serta dalam melaksanakan upacara tradisional. Sehingga penting adanya untuk meneliti upacara tradisional dengan berbagai aspek perubahannya dan 
komodifikasi budaya dalam hubungannya dengan pembentukan identitas komunitas.

Penelitian yang dilakukan oleh Rostiyati dan Susilantini (1995) menunjukkan telah terjadi perubahan atau pergeseran pada upacara tradisional Sekaten di Yogyakarta. Perubahan itu terjadi pada permukaannya (kulitnya), artinya mereka masih melakukan upacara tradisional tapi hanya dipersingkat atau digabung. Upacara tradisional Sekaten kini sudah mulai jarang dilakukan bahkan tidak dilakukan sama sekali. Berdasarkan hasil penelitian, sebagian besar informan mengatakan bahwa penyebab perubahan atau pergeseran ini adalah pengaruh komodifikasi. Seperti diketahui bahwa upacara tradisional Sekaten yang semula merupakan kegiatan keagamaan dan bermakna religius, dewasa ini telah menjadi suguhan wisata. Dimana dahulunya acara tersebut diisi dengan kesenian tradisional (srandul, ndolalak, kethèk ogleng, ledek munyuk, stambul, wayang uong, kroncong, dan ketoprak) namun kini acara tersebut diisi dengan kegiatan-kegiatan untuk kepentingan pariwisata dan pembangunan (acara rekreasi, pameran dari instansi pemerintah, dan pasar malam).

Studi kasus lainnya, yaitu upacara tradisional Seblang masyarakat Using Banyuwangi diketahui sejak lama kehilangan dimensi ritual kesuburannya dan beralih menjadi seni pertunjukkan yang sepenuhnya untuk memenuhi kebutuhan hiburan masyarakat sekitar atau para wisatawan (pariwisata) dan hanya mementingkan estetika dan etika. Upacara tradisional Seblang dengan segala perkembangannya seolah kini merupakan komoditas lain dari masyarakat dimana kebudayaan tersebut beredar dan berkembang. Sehingga pada tataran masyarakat, komodifikasi pun merubah orientasi seseorang dalam ikut serta dalam sebuah komunitas bukan hanya sebagai simbol solidaritas yang identik dalam komunitas melainkan lebih didominasi oleh gaya hidup. Keikutsertaan dalam sebuah komunitas dengan orientasi gaya hidup dilatarbelakangi oleh usaha hidup dalam "diri" yang mengikuti pasar dimana komunitas bukan sebagai "rumah" tetapi sebagai "panggung".

Kampung Budaya Sindangbarang adalah salah satu kampung adat dari 20 kampung adat yang ada di Jawa Barat. Kampung Budaya Sindangbarang adalah salah satu komunitas yang hingga kini mempertahankan aspek kebudayaan lokal kerajaan Pajajaran, dimana terdapat 78 lokasi situs sejarah Pakuan Sindangbarang, upacara tradisional (upacara adat Seren Taun, upacara adat Neteupken, upacara adat Pabeasan, dan berbagai upacara adat lainnya), dan berbagai kesenian tradisional Sunda. Hingga kini Kampung Budaya Sindangbarang memiliki daya tarik tersendiri bukan saja sebagai kampung adat, melainkan juga sebagai salah satu tempat alternatif wisata para wisatawan domestik dan mancanegara.

Kemampuan warga Kampung Budaya Sindangbarang untuk bertahan menjaga kelestarian upacara tradisional Seren Taun terhadap terpaan proses komodifikasi dapat dijadikan contoh bagaimana membentuk identitas komunitas dengan cara menjaga eksistensi kebudayaan tradisional. Berbagai motif dan perilaku yang dimiliki oleh warga Kampung Budaya Sindangbarang diduga membuat komunitas tersebut dapat menjaga eksistensi identitasnya. Kasus Kampung Budaya Sindangbarang diharapkan mampu menjawab berbagai persoalan tentang proses komodifikasi upacara tradisional dalam pembentukan identitas komunitas.

\section{Perumusan Masalah}

Berdasarkan latar belakang, perumusan masalah yang dikaji dalam penelitian ini adalah:

1. Sejauh mana komodifikasi upacara tradisional Seren Taun berhubungan dengan motif melaksanakan upacara tradisional Seren Taun warga Kampung Budaya Sindangbarang?

2. Sejauh mana motif melaksanakan upacara tradisional Seren Taun berhubungan dengan perilaku melaksanakan upacara tradisional Seren Taun warga Kampung Budaya Sindangbarang dalam pembentukan identitas komunitas?

\section{Tujuan Penelitian}

Berdasarkan identifikasi masalah yang telah dikemukakan sebelumnya, maka penelitian ini dilakukan dengan tujuan untuk:

1. Menganalisis hubungan komodifikasi upacara tradisional Seren Taun dengan motif melaksanakan upacara tradisional Seren Taun warga Kampung Budaya Sindangbarang.

2. Menganalisis hubungan motif melaksanakan upacara tradisional Seren Taun dengan perilaku melaksanakan upacara tradisional Seren Taun warga Kampung Budaya Sindangbarang dalam pembentukan identitas komunitas.

\section{Kegunaan Penelitian}

Adapun kegunaan penelitian ini, diantaranya:

\section{Civitas Akademik}

Hasil penelitian ini diharapkan dapat bermanfaat untuk menambah wawasan, pengetahuan, dan sebagai literatur ilmiah bagi penelitian berikutnya yang terkait permasalahan komodifikasi kebudayaan.

\section{Masyarakat}

Hasil penelitian ini diharapkan dapat dijadikan sebagai tambahan informasi mengenai komodifikasi upacara tradisional Seren Taun di Kampung Budaya Sindangbarang, motif-motif melaksanakan upacara, perilaku melaksanakan upacara tradisional Seren Taun, dan pranata yang mengaturnya.

\section{Pemerintah}

Hasil penelitian ini diharapkan dapat dijadikan pedoman bagi pemerintah untuk lebih memperhatikan komunitas dan budaya lokal. Hasil penelitian ini pun diharapkan dapat dijadikan bahan rujukan untuk pemerintah dalam membuat programprogram pengembangan masyarakat berbasis budaya komunitas lokal. 


\section{PENDEKATAN KONSEPTUAL}

\section{Tinjauan Pustaka}

\section{Identitas Komunitas}

Identitas sering memberikan tidak saja makna tentang pribadi seorang atau kelompok tetapi juga ciri khas sebuah kebudayaan yang melatarbelakanginya, dari ciri khas itulah dimungkinkan dapat mengungkapkan keberadaan orang atau kelompok itu. Menurut Alo (2002), pengertian identitas pada tataran hubungan antarmanusia ataupun antarkomunitas dipahami sebagai suatu hal yang lebih konseptual yakni tentang bagaimana meletakkan seseorang atau komunitas ke dalam tempat-tempat orang atau komunitas lain, atau sekurang-kurangnya membagi pikiran, perasaan, masalah, rasa simpatik, dan lain-lain dalam sebuah proses komunikasi (antarbudaya). Melihat pengertian yang diungkapkan oleh Alo (2002) tersebut dapat dikatakan bahwa identitas seseorang atau komunitas cenderung beradaptasi dengan struktur budaya dan struktur sosial yang hidup disekitarnya.

Berdasarkan hal tersebut, Wicandra (2006) menyatakan bahwa identitas akan selalu mengalami perubahan, pada kadar kecil apa pun sesuai dengan perubahan sejarah dan kebudayaan. Hal tersebut disebabkan adanya percepatan tempo kehidupan dalam masyarakat pasca industri, serta percepatan pergantian tanda, citra, makna, dan simbol yang menggiring ke dalam kondisi perubahan. Melihat pendapat-pendapat tersebut, maka identitas dapat dilihat sebagai rantai perubahan secara terus menerus, sebagai bentuk pelestarian masa lalu atau warisan budaya dan sebagai bentuk transformasi serta perubahan masa depan.

Membahas identitas sebagai sebuah karakteristik pembeda, penting adanya membahas komunitas sebagai salah satu unsur kebudayaan yang membutuhkan sebuah identitas dalam pembentukannya. Komunitas menurut Mac Iver dan Charles H. Page (Soekanto, 1982) diartikan sebagai kelompok sosial dimana setiap anggota kelompok tersebut harus sadar bahwa dia merupakan bagian dari kelompok yang bersangkutan dengan adanya hubungan timbal balik antara anggota yang satu dengan anggota lainnya di dalam kelompok tersebut. Selanjutnya Mac Iver (Soekanto, 1982) menjelaskan bahwa ada suatu faktor yang mengeratkan anggota-anggota dalam komunitas, sehingga hubungan antara mereka bertambah erat, yaitu nasib yang sama, kepentingan yang sama, tujuan yang sama dan ideologi politik yang sama. Komunitas menurut Soekanto (1982) diartikan sebagai kelompok sosial dengan wilayah tertentu dimana setiap anggota saling mengenal dan berinteraksi melalui berbagai peran yang memungkinkan menghargai, memproduksi, dan mengekspresikan budayanya. Berdasarkan pendapatpendapat tersebut, maka komunitas diartikan sebagai kelompok sosial yang setiap anggotanya sadar akan keanggotannya dalam kelompok tersebut sehingga terbentuk interaksi antar anggota kelompok untuk menghargai, memproduksi, dan mengekspresikan budayanya dalam kerangka geografis tertentu dengan ciri lokalitas tertentu.
Melihat kembali pendapat para ahli berkenaan dengan identitas dan komunitas, secara sederhana identitas komunitas diartikan sebagai suatu hal yang menjelaskan ciri dan karakteristik suatu kelompok sosial dimana para anggotanya berinteraksi untuk mengekspresikan kebudayaannya terhadap kelompok sosial lain. Dalam menentukan identitas komunitas, menurut Alo (2002), tidak hanya sekedar menentukan karakteristik ataupun ciri-ciri fisik semata tetapi juga mengkaji identitas komunitas tersebut melalui tatanan berpikir (cara berpikir, orientasi berpikir), perasaan (cara merasa dan orientasi perasaan), dan cara bertindak (motivasi tindakan atau orientasi tindakan). Hal tersebut mengindikasikan bahwa untuk menentukan identitas komunitas sangat bergantung pada kebudayaan (seluruh total pikiran, cara-cara berlaku, kepercayaankepercayaan, dan sikap-sikap yang khas dalam masyarakat atau kelompok sosial tertentu) baik material maupun non-material, yaitu bagaimana pengaktualisasian kebudayaan menjelaskan sebuah kenyataan atas semua identitas yang dibandingkan dengan identitas dalam komunitas yang lain.

\section{Perubahan Kebudayaan dalam Mempengaruhi Identitas Komunitas}

Kata "kebudayaan" berasal dari kata Sansekerta buddhayah yang merupakan bentuk jamak dari kata buddhi yang berarti budi atau akal. Dengan demikian kebudayaan dapat diartikan sebagai "hal-hal yang bersangkutan dengan budi atau akal". E. B. Taylor (Alo, 2002) memberikan definisi mengenai kebudayaan, yaitu sebagai berikut:

Kebudayaan adalah kompleks yang
mencakup pengetahuan, kepercayaan,
kesenian, moral, hukum, adat istiadat,
dan kemampuan-kemampuan serta
kebiasaan-kebiasaan yang didapatkan
oleh manusia sebagai anggota
masyarakat.

Dengan kata lain, kebudayaan mencakup kesemuanya yang didapatkan atau dipelajari oleh manusia sebagai anggota masyarakat. Kebudayaan terdiri dari segala sesuatu yang dipelajari dari pola-pola perilaku yang normatif, yaitu mencakup segala cara-cara atau polapola berpikir, merasakan, dan bertindak. Kebudayaan dari setiap bangsa atau masyarakat terdiri dari unsurunsur besar maupun kecil yang merupakan bagianbagian dari kesatuan. Seorang antropolog yaitu C. Kluckhohn (Soekanto, 1982) telah menguraikan unsurunsur kebudayaan, yaitu:

\section{Peralatan dan perlengkapan manusia}

2. Mata pencaharian hidup dan sistem-sistem ekonomi

3. Sistem kemasyarakatan (sistem kekerabatan, organisasi politik, sistem hukum, dan sistem perkawinan)

4. Bahasa (lisan maupun tulisan)

5. Kesenian

6. Sistem pengetahuan 


\section{Sistem kepercayaan}

Kebudayaan mempunyai fungsi yang sangat besar bagi manusia dan masyarakat. Khususnya dalam mengatur hubungan antar manusia, kebudayaan berfungsi sebagai penentu garis-garis pokok tentang perilaku yang menetapkan peraturan-peraturan mengenai apa yang harus dilakukan, apa yang seharusnya dilakukan, dan apa yang dilarang. Menurut Soekanto (1982), fungsi kebudayaan yaitu mengakomodir keinginan seseorang untuk menciptakan sesuatu guna menyatakan perasaan dan keinginannya pada orang lain ketika seseorang tersebut telah dapat mempertahankan dan menyesuaikan diri pada alam, dan ketika seseorang tersebut dapat hidup dengan manusia-manusia lain dalam suasana damai.

Berdasarkan uraian di atas, dapat dilihat bahwa kebudayaan pun memiliki fungsi dan peran dalam mempengaruhi pembentukan identitas komunitas. Perubahan-perubahan pada masyarakat-masyarakat di dunia dewasa ini yang dianggap sebagai gejala normal dimana pengaruhnya menjalar dengan cepat memiliki indikasi tersendiri terhadap identitas komunitas. Perubahan-perubahan dalam kebudayaan mencakup semua bagian kebudayaan termasuk di dalamnya kesenian, ilmu pengetahuan, teknologi, filsafat, dan lain-lain maupun perubahan-perubahan dalam bentuk serta aturan-aturan organisasi sosial. Adapun sebabsebab dari perubahan kebudayaan, yaitu:

\section{1) Bertambah dan berkurangnya penduduk}

Bertambahnya penduduk yang sangat cepat di pulau Jawa, menyebabkan terjadinya perubahan dalam struktur masyarakat, terutama yang menyangkut lembaga-lembaga kemasyarakatan. Berkurangnya penduduk pun akan merubah stratifikasi sosial masyarakat yang mempengaruhi lembaga-lembaga kemasyarakatan. Stratifikasi sosial yang berubah menciptakan adanya perbedaan dalam komunitas berkenaan dengan tingkat pendidikan, kekayaan, status, dan perbedaan kelas sosial yang mempengaruhi dalam gaya hidup dan tindakan dalam komunitas.

Adanya perbedaan dalam hal gaya hidup dan tindakan mempengaruhi komunitas dalam menetapkan nilai dan norma kehidupan komunitas. Hal tersebut akan mempengaruhi pembentukan nilai dan norma sebagai unsur kebudayaan yang telah lama dianut oleh sebuah komunitas untuk menentukan perannya dalam kehidupan bermasyarakat. Perubahan nilai dan norma tersebut cenderung menciptakan identitas baru dalam komunitas yang terikat oleh waktu dan tempat. Sebagaimana dikatakan oleh Wicandra (2006) bahwa identitas berusaha dibangun, digali, ditafsirkan sebagai bentuk pelestarian masa lalu dan sebagai bentuk transformasi serta perubahan masa depan melalui rantai perubahan secara terus menerus.

\section{2) Inovasi (teknologi)}

Inovasi (teknologi) merupakan suatu proses kebudayaan yang besar, tetapi yang terjadi dalam jangka waktu yang tidak terlalu lama (Soekanto, 1982). Proses tersebut meliputi suatu penemuan baru, jalannya kebudayaan baru yang tersebar ke lain-lain bagian dari masyarakat, dan cara-cara unsur kebudayaan tadi diterima, dipelajari, dan akhirnya dipakai dalam masyarakat yang bersangkutan (Alo, 2002). Utama (2009) menjelaskan bahwa inovasi yang muncul sebagai bagian faktor perubahan kebudayaan mempengaruhi pembentukan identitas baik dalam taraf komunitas maupun kebangsaan.

Dijelaskan dalam perspektif materialis, teknologi sangat determinan dalam perubahan kebudayaan. Teknologi akan berkembang dengan sangat cepat karena basic culture memungkinkan untuk itu. Adapun cara teknologi mempengaruhi kebudayaan, yaitu, pertama, teknologi meningkatkan alternatif-alternatif baru bagi manusia. Kedua, teknologi mempengaruhi dan kemudian mengubah pola interaksi. Bila demikian, maka tingkat percepatan perkembangannya akan jauh meninggalkan kebudayaan manusia. Maka, seiring dengan kecenderungan tersebut, munculah konsep culture lag. Apabila fenomena ini terjadi, maka akan terjadi pengaburan pada komunitas dalam membentuk identitasnya, dimana nilai, norma, kegiatan ritual, dan segala unsurnya telah terabaikan dalam setiap perilaku anggotanya.

\section{3) Modernisasi}

Soekanto (1982) menjelaskan bahwa modernisasi merupakan suatu proses perubahan yang menuju pada tipe sistem-sistem sosial, ekonomi, dan politik yang telah berkembang dengan pesat di Eropa barat dan Amerika Utara pada abad ke-17 sampai pada abad ke19. Dalam pengertian yang lain, modernisasi menyangkut aspek-aspek sosio-demografis masyarakat (unsur-unsur sosial ekonomis dan psikologis) yang menuju ke arah pola-pola baru melalui sosialisasi dan pola-pola perilaku yang berwujud pada aspek kehidupan modern (mekanisme, media yang teratur, dan urbanisasi). Berdasarkan pengertian mengenai modernisasi tersebut, terlihat bahwa modernisasi sebagai salah satu faktor perubahan dalam tataran sosial masyarakat memiliki peluang yang cenderung besar dalam perubahan kebudayaan.

Adapun dijelaskan dalam realitas sosial, modernisasi merupakan penyebab atau perubahan yang disebabkan adanya pengaruh zaman yang sudah maju. Kaitannya dengan kebudayaan, modernisasi merubah kebudayaan melalui beberapa faktor, yaitu membuat manusia berpikir rasional, pengaruh agama, membuat manusia mulai berpikir ekonomis, gaya hidup, dan perubahan politik. Senada dengan Soekanto (1982), Effendy dan Anoegrajekti (2004) modernisasi meliputi:

\section{a. Berkembangnya ilmu pengetahuan}

Ketika manusia telah berpikir rasional, menggunakan nalar, sistematis, dan praktis, maka yang terjadi adalah perubahan dalam cara-cara berpikir, ide atau nilai dari metafisik ke positif, empiris dan rasional. Perubahan cara berpikir ini membawa implikasi pada perubahan kebudayaan. Hal inilah yang terjadi pada kebudayaan upacara tradisional pada masyarakat Yogyakarta, dimana kini pelaksanaan upacara tradisional pada masyarakat Yogyakarta telah dipersingkat, digabung, 
bahkan dihilangkan sebagai akibat manusia telah berpikir rasional (Rostiyati dan Susilantini, 1995). Ketika kebudayaan dipersingkat, digabung, bahkan dihilangkan, maka yang terjadi adalah pengaburan identitas komunitas dimana setiap anggota tidak hanya kehilangan karakteristik, nilai, ataupun norma yang terkandung dalam kebudayaan melainkan interaksi dalam komunitas pun luntur dalam ciri khas lokalitasnya, menciptakan individualisme.

\section{b. Berkembangnya agama islam}

Modernisasi pun mencakup masuknya pengaruh agama dalam kehidupan komunitas, khususnya agama islam. Hal ini disebabkan banyaknya pengajian, ceramah, khotbah, dan lain sebagainya menyebabkan komunitas mulai meninggalkan kebudayaannya yang dianggap tidak sesuai dengan ajaran agama. Ajaran agama yang diterima oleh anggota komunitas menciptakan pretensi negatif atau pola pikir baru yang cenderung secara radikal menganggap kebudayaan merupakan suatu hal yang berkaitan dengan maksiat, perusak akhlak, dan tidak sesuai dengan kepribadian bangsa. Hal ini akan mengakibatkan pengemasan ulang kebudayaan bahkan pemusnahan, dimana pada tataran berikutnya identitas komunitas pun digali, dicari, dan dikemas dalam bentuk yang baru (Effendy dan Anoegrajekti, 2004). Berdasarkan hal tersebut, adapun dua faktor yang memacu perubahan dari kondisi kepercayaan komunitas yang berciri sebagai kelompok sosial ke arah agama yang terorganisasi secara khusus. Pertama, meningkatkan secara total "perubahan batin" atau kedalaman beragama. Karena pembagian kerja dalam komunitas kian berkembang yang kemudian melahirkan alokasi fungsi, alokasi fasilitas, serta sistem imbal jasa yang semakin kompleks, maka komunitas cenderung mengembangkan suatu tingkat spesifikasi yang lebih tinggi. Kemudian tampilah kelompok-kelompok dengan tujuan yang lebih jelas dan terperinci untuk melaksanakan berbagai kegiatan, termasuk agama. Kedua, meningkatnya pengalaman keagaman yang mengambil bentuk berbagai corak organisasi keagaman baru. Dengan demikian perkembangan komunitas dalam beragama mengikuti perkembangan organisasi keagaman yang khusus menjadikan komunitas menuju perubahan-perubahan keyakinan dan kepercayaan kepada kedalaman beragama, yaitu agama islam

\section{4) Ekonomi-politik (komersialisasi)}

Sejak Jepang datang ke Indonesia khususnya Jawa, hal ini membatasi masyarakat untuk menjalankan kepercayaannya sebagai bagian dari kebudayaan komunitas pada saat itu (Rostiyati dan Susilantini, 1995). Dewasa ini kebudayaan telah berubah menjadi alat mobilisasi kepentingan politik, dimana kebudayaan yang berkembang dalam komunitas digunakan ataupun dilaksanakan bukan hanya didasarkan pada nilai esensi yang terkandung didalamnya melainkan efektifitasnya dalam menghimpun massa (Effendy dan Anoegrajekti, 2004).

Dijelaskan dalam tataran ekonomi, kebudayaan merupakan "tontonan" yang dapat diperjualbelikan, dimana komunitas diharuskan mengemas ulang kebudayaannya berdasarkan keinginan pasar. Hal tersebut telah diungkapkan oleh Utama (2009) dimana komunitas harus memikirkan cara mengemas kebudayaan, melakukan survai pasar untuk memahami minat dan selera konsumen, dan akhirnya melakukan transaksi. Menurut pemikiran Abdullah (Utama, 2009), ketika kepentingan politik menjadi dasar penghargaan terhadap suatu kebudayaan, maka yang terjadi adalah makna politis yang terkandung dalam kebudayaan tersebut, dimana komunitas tidak lagi melihat kebudayaan dengan segala makna adiluhurnya yang mengatur hubungan manusia dengan Tuhannya, manusia dengan manusia, dan manusia dengan alamnya, sebagai sebuah identitas, melainkan hanya sebatas kehidupan yang berorientasi pada proses transaksional.

\section{Pengaruh Komodifikasi Kebudayaan terhadap Identitas Komunitas}

Menurut Surbakti (2009), komodifikasi adalah proses yang diasosiasikan dengan kapitalisme dimana objek, kualitas, dan simbol dijadikan sebagai komoditas yang tujuan utamanya adalah untuk dijual di pasar. Menurut Surbakti (2009), diketahui bahwa komodifikasi kebudayaan merupakan kombinasi kekuatan pemerintah dan kekuatan modal (pengusaha) yang berimplikasi pada berubahnya wajah dan estetika komunitas, sejarah terbentuknya mulai dilupakan, dan identitas komunitas menjadi kabur. Berdasarkan pendapat tersebut, Utama (2009) menunjukkan fakta bahwa "nilai tinggi" kebudayaan tidak sekedar diukur dengan menunjuk pada kandungan filosofis atau kearifan tradisional tetapi dapat dilihat pula dari nilai rupiah atau harga jualnya. Hal tersebut mengindikasikan bahwa pemberian penghargaan atas status kebudayaan sebagai kebudayaan yang bernilai tinggi pun lalu berfungsi sebagai semacam iklan yang dapat mendongkrak penjualan produk-produk kebudayaan yang telah diproduksi dan direproduksi (budaya dibangun dan diciptakan ulang) dengan kemasan baru. Pada saat kebudayaan telah mengalami komodifikasi maka diplomasi kebudayaan pun menjadi sebuah proyek yang mendatangkan keuntungan besar. Hal tersebut dapat dilihat dari peningkatan jumlah wisatawan, pameran kebudayaan, publikasi kebudayaan melalui media massa, dan banyaknya pengunjung pameran yang menjadi lebih dipentingkan daripada peningkatan apresiasi dan kearifan sikap pemerintah dan masyarakat yang merefleksikan multikulturalisme.

Banindro (2007) mencoba menjelaskan pengaruh komodifikasi kebudayaan terhadap pembentukan identitas komunitas melalui gaya psychedelia sebagai gerakan idealis anti kemapanan. Banindro (2007) melihat komodifikasi gaya psychedelia yang pada awal kemunculannya sebagai gaya atau gerakan komunitas yang memiliki pandangan melawan budaya kemapanan berubah sebagai gaya hidup remaja yang dituangkan dalam produk make up, fashion, meubel, sepatu, otomotif, elektronik, bahkan tattoo, dianggap sebagai proses komodifikasi kebudayaan. Komodifikasi kebudayaan tidak hanya sebagai proses perdagangan kebudayaan, melainkan sebuah pengalihan dan 
manipulasi hasil-hasil pikiran komunitas menjadi komoditas. Hal ini mengindikasikan sebuah kebudayaan dalam komunitas dimunculkan kembali tidak serta merta sama persis, bahkan terkait dengan konsep nilai kapitalistik yang pada akhirnya memunculkan komodifikasi.

Berdasarkan realitas sosial yang terjadi terlihat bahwa pemerintah hanya memproduksi nilai ekonomis terhadap kebudayaan yang sebenarnya telah dibentuk oleh komunitas sebagai identitasnya melalui kesenian, ritual, dan berbagai simbol-simbol. Namun pemerintah dengan paham nasionalismenya "merebut" simbolsimbol komunitas tersebut menjadi simbol bersama yaitu simbol kebangsaan yang secara radikal diperdagangkan. Implikasi yang muncul dalam kehidupan komunitas adalah identitas sebagai karakteristik komunitas terus menerus luruh, dan yang tampil di permukaan adalah perasaan bahwa mereka warga dari suatu komunitas yang sama. Luruhnya identitas komunitas sebagai akibat penyeragaman tidak lain disebabkan karena adanya ekspansi pasar, pengaruh etos kerja kapitalistik, dan masyarakat yang berorientasi pada pasar (transaksi) dimana tidak hanya mempengaruhi kehidupan suatu komunitas, tetapi juga mempengaruhi sistem nilai dan tata hubungan sosial (Utama, 2009).

Di sisi lain komodifikasi kebudayaan pun merubah orientasi manusia dalam membentuk maupun ikut serta dalam sebuah komunitas, bukan hanya sebagai simbol solidaritas yang identik dalam komunitas, melainkan lebih didominasi oleh gaya hidup. Keikutsertaan dalam sebuah komunitas dengan orientasi gaya hidup dilatarbelakangi oleh usaha hidup dalam tampilan "diri" yang mengikuti pasar dimana komunitas bukan sebagai "rumah" tetapi sebagai "panggung" (Wicandra, 2006). Hal ini memperlihatkan bahwa komunitas tidak lagi dibangun dalam kerangka membentuk identitas dengan segala karakteristik kebudayaannya, melainkan dibentuk berdasarkan perkembangan pasar melalui komodifikasi kebudayaan.

\section{Upacara Tradisional Seren Taun}

Menurut Intani dan Andayani (2006), Seren Taun berasal dari dua kata yaitu kata Seren dan Taun. Seren berasal dari kata serah atau menyerahkan dan Taun berasal dari kata tahun. Berdasarkan hal tersebut, arti Seren Taun menurut makna katanya adalah serah terima tahun yang lalu ke tahun yang akan datang sebagai penggantinya. Upacara tradisional Seren Taun adalah upacara adat masyarakat Sunda yang dilakukan tiap tahun yaitu pada tanggal 22-Raya agung-bulan terakhir pada sistem penanggalan Sunda yang menggambarkan tentang bagaimana manusia senantiasa bersyukur kepada Tuhan Yang Maha Kuasa, terlebih dikala menghadapi panen. Upacara ini juga dimaksudkan agar Tuhan memberikan perlindungan di masa tanam mendatang.

Adapun dalam konteks kehidupan tradisi masyarakat peladang Sunda, Seren Taun merupakan wahana untuk bersyukur kepada Tuhan Yang Maha Esa atas segala hasil pertanian yang dilaksanakan pada tahun ini, dan berharap hasil pertaniannya akan meningkat pada tahun yang akan datang. Upacara Seren Taun merupakan acara penyerahan hasil bumi berupa padi yang dihasilkan dalam kurun satu tahun untuk disimpan ke dalam lumbung atau dalam bahasa Sunda disebut leuit.

Terdapat dua macam Leuit, yaitu Leuit Ratna Inten atau Leuit Indung (lumbung utama) dan Leuit Pangiring atau Leuit Kecil (lumbung kecil). Leuit Ratna Inten selain sebagai tempat menyimpan pare ambu (padi ibu) yang ditutupi oleh kain putih dan pare ayah (padi bapak) yang ditutupi olah kain hitam, juga tempat menyimpan padi yang lainnya. Kedua padi tersebut digunakan untuk bibit atau benih pada musim tanam yang akan datang. Leuit Pangiring menjadi tempat menyimpan padi yang tidak tertampung di Leiut Ratna Inten.

Menurut Intani dan Andayani (2006), upacara tradisional Seren Taun dilaksanakan pada tanggal 18Raya agung bulan terakhir pada sistem penanggalan Sunda hingga 22-Raya agung bulan terakhir pada sistem penanggalan Sunda. Tahapan upacara tradisional Seren Taun diawali dengan prosesi Ngajayak (menyambut atau menjemput padi) sampai membawa hasil bumi dari 4 penjuru. Dalam pelaksanaan upacara tradisional Seren Taun terdapat beberapa makna yang terkandung didalamnya, yaitu ngajayak dalam bahasa Sunda berarti menerima dan menyambut, sedangkan bilangan 18 yang dalam bahasa Sunda diucapkan "dalapan welas" berkonotasi welas asih yang artinya cinta kasih serta kemurahan Tuhan yang telah menganugerahkan segala kehidupan bagi umat-Nya di segenap penjuru bumi. Bilangan 22 dimaknai sebagai rangkaian bilangan 20 dan 2 .

Padi yang ditumbuk pada puncak acara sebanyak 22 kwintal dengan pembagian 20 kwintal untuk ditumbuk dan dibagikan kembali kepada masyarakat dan 2 kwintal digunakan sebagai benih. Bilangan 20 merefleksikan unsur anatomi tubuh manusia. Empat penjuru tersebut sebagai simbol yang melambangkan cinta kasih Tuhan terhadap umatnya di 4 penjuru. Menurut Intani dan Andayani (2006) bahwa dalam pelaksanaan upacara tradisional Seren Taun terdapat beberapa kesenian, yaitu:

1. Damar Sewu, yaitu sebuah helaran budaya yang merupakan gambaran manusia dalam menjalani proses kehidupan baik secara pribadi maupun sosial.

2. Tari Buyung, yaitu sebuah helaran budaya yang merupakan gambaran manusia dalam menjalani proses kehidupan baik secara pribadi maupun sosial.

3. Pesta Dadung, yaitu upaya meruwat dan menjaga keseimbangan alam agar hama dan unsur negatif tidak menggangu kehidupan manusia.

4. Ngamamerokeun, yaitu upacara ini berintikan "mempertemukan dan mengawinkan" benih padi jantan dan betina.

5. Tarawangsa, yaitu seni yang berasal dari Mataram kira-kira abad ke XV, seni Tarawangsa disebut juga seni Jentreng, menginduk kepada suara Kecapi, juga ada yang menamai seni Ngekngek, menginduk kepada suara Tarawangsa. Mula-mula yang

178 | Prasetyo, Untung. et. al. Komodifikasi Upacara Tradisional Seren Taun dalam Pembentukan Identitas Komunitas 
dipentaskan hanya tabuhan Kecapi dan Tarawangsa saja, tapi disertai penari, agar lebih menarik akhirnya Tarawangsa dilengkapi dengan tarian-tarian sederhana yang disebut tari Badaya.

6. Seribu Kentongan, memiliki makna bahwa kentongan awi (bambu) memiliki arti kita harus senantiasa ingat dan eling pada hukum adikodrati yang menentukan nilai kemanusian dan kebangsaan. Seribu Kentongan merupakan acara penutup rangkaian acara Seren Taun. Lebih dari 1000 orang terdiri dari masyarakat dan anak-anak sekolah serta seluruh peserta pendukung rangkaian acara Seren Taun ikut serta dalam prosesi ini, ditutup dengan 10 orang rampak kendang. Dimulai dengan pukulan induk oleh Ketua Adat kemudian diikuti oleh ribuan peserta.

Menurut Intani dan Andayani (2006), ditemukan adanya penggunaan simbol dalam upacara tradisional Seren Taun. Hal tersebut termasuk pada jenis simbol dan makna yang terkandung dalam simbol tersebut. Simbolsimbol tersebut yaitu:

1. Dewi Sri, yaitu tokoh yang telah melegenda dan memiliki daya tarik tersendiri bagi masyarakat agraris khususnya tatar Sunda.

2. Tari Pwah Aci merupakan salah satu seni tari spiritual yang di dalamnya tersirat ungkapan rasa hormat dan bhakti kepada Sang Pemberi Hidup melalui gerak dan ekspresi.

3. Buyung, yaitu sejenis alat yang terbuat dari logam maupun tanah liat yang digunakan oleh sebagian wanita desa pada zaman dulu untuk mengambil air di sungai, danau, mata air, atau di kolam.

4. Menginjak kendi sambil membawa buyung di kepala, yaitu erat relevansinya dengan ungkapan "di mana bumi di pijak di situ langit dijunjung". Hal ini berarti bahwa dalam kehidupan ini perlu adanya keseimbangan antara perasaan dan pikiran.

5. Pergelaran tari buyung dengan formasi, yaitu memiliki makna yang menyiratkan bahwa masyarakat Sunda adalah masyarakat yang religius.

\section{Kerangka Pemikiran}

Kerangka pemikiran ini mencoba menggambarkan adanya hubungan antara upacara tradisional Seren Taun dengan pembentukan identitas komunitas Kampung Budaya Sindangbarang dalam hal motif melaksanakan upacara tradisional Seren Taun dan perilaku melaksanakan upacara tradisional Seren Taun. Identitas Komunitas Kampung Budaya Sindangbarang adalah suatu hal yang menjelaskan ciri dan karakteristik warga Kampung Budaya Sindangbarang, dimana para warganya berinteraksi dan berperilaku untuk mengekspresikan kebudayaannya terhadap kelompok sosial lain.

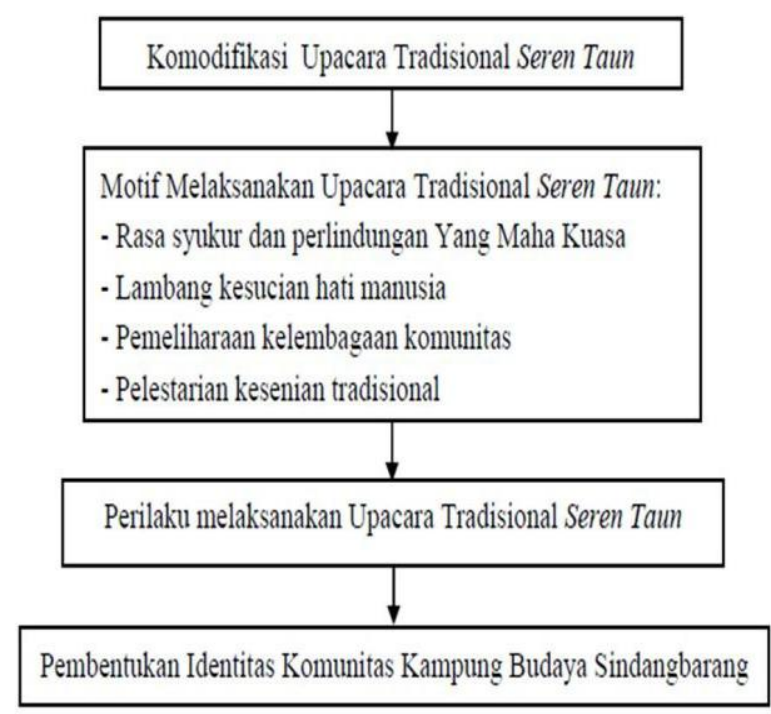

\section{Gambar 1. Kerangka Pemikiran Komodifikasi Upacara Tradisional Seren Taun dalam Pembentukan Identitas Komunitas}

Kerangka pemikiran ini menjelaskan bahwa apabila komodifikasi upacara tradisional Seren Taun memiliki hubungan dengan motif melaksanakan upacara tradisional Seren Taun maka akan diketahui hubungan dengan pembentukan identitas komunitas Kampung Budaya Sindangbarang. Selain itu, diduga pula komodifikasi upacara tradisional Seren Taun memiliki hubungan dengan perilaku melaksanakan upacara tradisional Seren Taun, sehingga akan diketahui komunitas dalam membentuk identitasnya -apakah identitas komunitas tersebut menjadi kuat atau apakah identitas komunitas tersebut menjadi lemah- sehingga akan diketahui hubungan antara komodifikasi upacara tradisional Seren Taun dengan pembentukan identitas komunitas Kampung Budaya Sindangbarang.

\section{Hipotesis Penelitian}

Berbagai karakteristik kebudayaan yang diungkapkan oleh Alo (2002) yang mempengaruhi pembentukan identitas komunitas dan telah diuraikan dalam kerangka pemikiran, maka terdapat hipotesis yang akan dikaji pada penelitian ini, yaitu:

1. Semakin tinggi komodifikasi upacara tradisional Seren Taun, maka semakin rendah motif melaksanakan upacara tradisional Seren Taun.

2. Semakin rendah motif melaksanakan upacara tradisional Seren Taun, maka semakin rendah perilaku melaksanakan upacara tradisional Seren Taun.

3. Semakin rendah perilaku melaksanakan upacara tradisional Seren Taun, maka semakin lemah pembentukan identitas komunitas Kampung Budaya Sindangbarang.

\section{Definisi Operasional}

Adapun untuk menjelaskan sesuatu yang abstrak menjadi konkrit, maka dibuatlah definisi operasional sebagai berikut: 
I. Motif melaksanakan upacara tradisional Seren Taun adalah alasan-alasan tiap individu untuk ikut serta melaksanakan upacara tradisional Seren Taun.

a. Rasa syukur dan perlindungan Yang Maha Kuasa adalah alasan tiap individu untuk ikut serta dalam melaksanakan upacara tradisional Seren Taun untuk menunjukkan rasa terima kasih pada Tuhan Yang Maha Kuasa dan harapannya untuk mendapatkan perlindungan dari Tuhan Yang Maha Kuasa.

b. Lambang kesucian hati manusia adalah alasan tiap individu untuk ikut serta dalam melaksanakan upacara tradisional Seren Taun yang didasarkan pada kesadarannya untuk membersihkan hati, pikiran, dan dirinya dari kesalahan dan kekurangan, serta didalamnya termasuk pada rasa hormat pada Yang Maha Kuasa untuk mendapatkan kesejahteraan.

c. Pemeliharaan kelembagaan komunitas adalah alasan tiap individu untuk ikut serta dalam melaksanakan upacara tradisional Seren Taun untuk menjaga tata aturan (norma dan nilai-nilai) dalam komunitas yang memberikan pedoman berperilaku, menjaga keutuhan komunitas, dan kepatuhan terhadap leluhurnya.

d. Pelestarian kesenian tradisional adalah alasan tiap individu ikut serta dalam melaksanakan upacara tradisional Seren Taun yang bertujuan untuk menghidupkan kembali, memperkenalkan, dan melestarikan kesenian tradisional Sunda kepada khalayak.

Masing-masing komponen pada motif melaksanakan upacara tradisional Seren Taun akan dijabarkan dalam bentuk pernyataan yang terangkum dalam kuesioner. Total keempat komponen untuk masing-masing motif melaksanakan upacara tradisional Seren Taun adalah 16 pernyataan. Setiap pernyataan dibagi dalam dua kategori dengan bobot 1-2.

1. $Y a$, skor $=2$

2. Tidak, skor $=1$

Total minimum dan total maksimum untuk semua pernyataan dalam tiap-tiap motif melaksanakan upacara tradisional Seren Taun adalah 23 dan 32, dengan nilai standar deviasi yaitu 1,8. Kriteria motif melaksanakan upacara tradisional Seren Taun dalam hubungannya dengan perilaku melaksanakan upacara tradisional Seren Taun kaitannya dengan pembentukan identitas:

a. Rendah : Apabila skor total variabel berada pada rentang 23,0-29,7

b. Sedang : Apabila skor total variabel berada pada rentang 29,8-31,5

c Tinggi : Apabila skor total variabel berada pada rentang 31,6-32,0
II. Perilaku melaksanakan upacara tradisional Seren Taun adalah segala aktivitas dan keikutsertaan anggota komunitas dalam melaksanakan upacara tradisional Seren Taun baik pada saat persiapan upacara, saat acara puncak, maupun saat akhir upacara.

Pada perilaku melaksanakan upacara tradisional Seren Taun akan dijabarkan dalam bentuk pernyataan yang terangkum dalam kuesioner. Total pernyataan untuk perilaku melaksanakan upacara tradisional Seren Taun adalah 10 pernyataan. Setiap pernyataan dibagi dalam dua kategori dengan bobot $1-2$.

1. $Y a$, skor $=2$

2. Tidak, skor $=1$

Total minimum dan total maksimum untuk semua pernyataan dalam tiap-tiap perilaku melaksanakan upacara tradisional Seren Taun adalah 12 dan 19, dengan nilai standar deviasi yaitu 1,3. Kriteria perilaku melaksanakan upacara tradisional Seren Taun dalam hubungannya dengan pembentukan identitas komunitas:

a. Rendah : Apabila skor total variabel berada pada rentang 12,0-16,6

b. Sedang : Apabila skor total variabel berada pada rentang $16,7-17,9$

c. Tinggi : Apabila skor total variabel berada pada rentang 18,0-19,0

III. Komodifikasi upacara tradisional Seren Taun adalah kegiatan pengemasan ulang dan perubahan bentuk, kualitas serta simbol dalam upacara tradisional untuk dijadikan komoditas yang dapat diperjualbelikan.

Pada komodifikasi upacara tradisional Seren Taun akan dijabarkan dalam bentuk pernyataan yang terangkum dalam kuesioner. Total pernyataan untuk komodifikasi upacara tradisional Seren Taun adalah 8 pernyataan. Setiap pernyataan dibagi dalam dua kategori dengan bobot 1-2.

\section{1. $Y a$, skor $=2$ \\ 2. Tidak, skor $=1$}

Total minimum dan total maksimum untuk semua pernyataan adalah 8 dan 16, dengan nilai standar deviasi 2,0. Kriteria komodifikasi upacara tradisional Seren Taun dalam hubungannya dengan motif dan perilaku melaksanakan upacara tradisional Seren Taun dalam pembentukan identitas komunitas:

a. Rendah : Apabila skor total variabel berada pada rentang 8,0-10,0

b. Sedang : Apabila skor total variabel berada pada rentang 10,1-13,0

c. Tinggi : Apabila skor total variabel berada pada rentang 13,1-16,0 


\section{METODOLOGI PENELITIAN}

\section{Lokasi dan Waktu Penelitian}

Penelitian ini dilakukan di Kampung Budaya Sindangbarang, Desa Pasireurih, Kecamatan Tamansari, Kabupaten Bogor, Jawa Barat, dimana penentuan lokasi dilakukan secara sengaja (purposive). Pemilihan lokasi ini didasarkan atas beberapa pertimbangan, yaitu: (1) Lokasi tersebut sesuai dengan topik penelitian dimana lokasi tersebut terdapat komunitas yang melaksankan upacara tradisional Seran Taun, (2) memiliki keunikan dalam realitas sosial dimana lokasi tersebut memiliki tantangan dalam mempertahankan kultur budayanya seiring dengan banyaknya wisatawan yang berkunjung, dan (3) Kampung Budaya Sindangbarang telah menjadi salah satu Tourism Oriented sehingga terdapat proses komodifikasi kebudayaan (upacara tradisional) di dalamnya. Penelitian ini dilakukan pada bulan September-Oktober 2010. Kurun waktu penelitian yang dimaksud mencakup waktu semenjak penelitian intensif berada di lokasi penelitian, sehingga penjajagan tidak termasuk dalam kurun waktu tersebut.

\section{Metode Penelitian}

Penelitian ini dilakukan dengan pendekatan kuantitatif. Pendekatan kuantitatif dilakukan melalui metode survai dengan maksud untuk penjelasan (explanatory), yaitu menjelaskan hubungan kausal antara variabel-variabel melalui pengujian hipotesa (Singarimbun dan Effendi, 1995). Adapun hubungan kausal yang dijelaskan adalah antara variabel-variabel yang berpengaruh terhadap pembentukan identitas komunitas Kampung Budaya Sindangbarang, yaitu: (1) Komodifikasi upacara tradisional Seren Taun, (2) motif melaksanakan upacara tradisional Seren Taun, (3) perilaku melaksanakan upacara tradisional Seren Taun. Untuk memperkaya data dan memahami fenomena yang sedang diteliti, maka ditambahkan informasi kualitatif pada penelitian ini. Tambahan informasi diperoleh melalui wawancara bebas dan observasi.

\section{Populasi dan Teknik Sampling}

Populasi dalam penelitian ini adalah warga Kampung Budaya Sindangbarang yang melaksanakan upacara tradisional Seren Taun. Sampel pada penelitian ini berjumlah tiga puluh orang dengan menggunakan Simple Random Sampling. Pada metode ini peneliti menggunakan pengundian nama-nama yang akan dijadikan sampel sesuai dengan jumlah sampel yang direncanakan, dimana sebelumnya peneliti telah membuat daftar nama warga Kampung Budaya Sindangbarang yang melaksanakan upacara tradisional Seren Taun.

\section{Teknik Pengumpulan Data}

Pada penelitian survai, data dikumpulkan dari sampel dengan menggunakan kuesioner yang bertujuan untuk memperoleh informasi yang relevan dengan tujuan survai (Singarimbun dan Effendi, 1995). Pernyataan dalam kuesioner juga berkaitan langsung dengan hipotesis dan tujuan penelitian. Pernyataan-pernyataan dalam kuesioner disusun berdasarkan hasil penjajagan peneliti ke lapangan. Penjajagan dilakukan oleh peneliti agar mendapatkan gambaran upacara tradisional Seren Taun yang berkaitan dengan motif dan perilaku melaksanakan upacara tradisional Seren Taun dalam pembentukan identitas komunitas. Dengan melakukan penjajagan terlebih dahulu, peneliti lebih mudah dalam menyusun kuesioner dan mendapatkan gambaran yang akurat mengenai komodifikasi upacara tradisional Seren Taun dalam pembentukan identitas komunitas Kampung Budaya Sindangbarang.

\section{Pengolahan dan Analisis Data}

Jawaban yang diperoleh dari kuesioner yang berupa raw data kemudian dikelompokkan berdasarkan variabelnya dalam bentuk transfer sheet. Adapun variabel yang dikelompokkan yaitu motif melaksanakan upacara tradisional Seren Taun. Selanjutnya data yang terkumpul diolah dengan menghitung jumlah data dan persentase responden menurut kategori variabel-variabel tersebut.

Uji statistik yang digunakan untuk mengetahui hubungan komodifikasi upacara tradisional Seren Taun dengan motif melaksanakan upacara tradisional Seren Taun dan hubungan motif melaksanakan upacara tradisional Seren Taun dengan perilaku melaksanakan upacara tradisional Seren Taun adalah analisis crosstabs yang menunjukkan hubungan kausal antara dua variabel. Analisis crosstabs merupakan analisis dasar untuk hubungan antar variabel kategori (nominal atau ordinal) dimana analisis crosstabs yang digunakan adalah analisis Pearson. Tabel silang dari uji Pearson membantu peneliti dalam mendeskripsikan apakah hasil penelitian sesuai dengan hipotesis yang diajukan.

\section{GAMBARAN UMUM DESA PASIREURIH}

\section{Letak dan Kondisi Goegrafis}

Secara administratif, Kampung Budaya Sindangbarang termasuk ke dalam wilayah Desa Pasireurih, Kecamatan Taman Sari, Kabupaten Bogor, Provinsi Jawa Barat. Menuju Desa Pasireurih jarak yang harus ditempuh dari pusat pemerintahan Kecamatan, yakni sekitar dua kilometer; sekitar 15 kilometer dari ibukota Kabupaten Bogor; sekitar 110 kilometer dari ibukota Provinsi Jawa Barat, Bandung; dan sekitar 62 kilometer dari ibukota Republik Indonesia, Jakarta.

Lokasi Desa Pasireurih cukup mudah dijangkau, baik menggunakan kendaraan umum maupun kendaraan pribadi. Ada angkutan kota serta ojeg yang beroperasi melayani penumpang ke sana. Kendaraan-kendaraan tersebut melalui jalan kabupaten 5 kilometer dan jalan desa sepanjang 10 kilometer. Kondisi jalannya cukup baik dan terpelihara.

Desa Pasireurih secara geografis berada pada ketinggian 300 meter di atas permukaan laut. Suhu udara minimum di daerah tersebut adalah 30 derajat celsius dan suhu maksimumnya mencapai 45 derajat celsius. Meskipun demikian, nuansa alam pedesaan masih dapat dilihat dan dirasakan. Hal tersebut ditandai dengan hamparan lahan persawahan yang cukup luas, yakni 28 hektar. 
Komposisi pemanfaatan lahan Desa Pasireurih secara keseluruhan dapat dilihat pada Tabel 1.

Tabel 1. Persentase Pemanfaatan lahan Desa Pasireurih, Kecamatan Tamansari,

\begin{tabular}{|c|c|c|c|}
\hline \multicolumn{4}{|c|}{2009} \\
\hline No. & Pemanfaatan Lahan & Luas (Hektar) & Persentase (\%) \\
\hline 1. & Persawahan & 28,00 & 59,74 \\
\hline 2. & Perladangan & 10,00 & 21,34 \\
\hline 3. & Lapangan olahraga & 3,00 & 6.40 \\
\hline 4. & Kuburan & 4,00 & 8,53 \\
\hline 5. & Kantor desa & 0,07 & 0,15 \\
\hline 6. & Jalan desa & 0,10 & 0,21 \\
\hline 7. & Prasarana umum lainnya & 1,70 & 3,63 \\
\hline & Jumlah & 46,87 & 100,00 \\
\hline
\end{tabular}

Sumber: Monografi Desa Pasireurih, 2009

\section{Kependudukan}

Jumlah penduduk yang tercatat di kantor Desa Pasireurih kurang lebih 10.864 orang, yang terbagi menjadi 1.850 kepala keluarga. Keseluruhan jumlah penduduk tersebut meliputi 5.632 orang perempuan dan 5.232 orang laki-laki, mayoritas berasal dari suku bangsa Sunda. Jumlah penduduk tersebut tinggal tersebar di seluruh wilayah desa, yang terdiri atas 14 rukun warga (RW) dan 54 rukun tetangga (RT). Pembagian tersebut dilakukan untuk kemudahan dalam urusan pengelolaan administrasi pemerintahan.

Mata pencaharian penduduk Desa Pasireurih dapat dikatakan heterogen. Komposisi bidang pekerjaan penduduk Desa Pasireurih secara keseluruhan dapat dilihat pada Tabel 2

Tabel 2. Persentase Penduduk Desa Pasireurih berdasarkan Mata Pencaharian
\begin{tabular}{|l|l|r|}
\hline No. & \multicolumn{1}{|c|}{ Jenis Pekerjaan } & Persentase \\
\hline 1. & Petani & 69,13 \\
\hline 2. & Pengrajin & 9,70 \\
\hline 3. & Pedagang & 8,57 \\
\hline 4. & Pengemudi/ Jasa & 6,12 \\
\hline 5. & Pegawai Negeri Sipil & 5,00 \\
\hline 6. & TNI & 0,34 \\
\hline 7. & Pensiunan & 1,22 \\
\hline \multicolumn{2}{|c|}{ Jumlah (\%) } & 100,00 \\
\hline
\end{tabular}

Sumber: Monografi Desa Pasireurih, 2009

Data pada Tabel 2 menunjukkan pekerjaan yang banyak digeluti oleh masyarakat Desa Pasireurih adalah bidang pertanian. Kategori petani dapat dibedakan menjadi 3 jenis, yaitu petani pemilik, petani penggarap, dan buruh tani. Petani menanam padi dan palawija sebagai selingan ke waktu tanam berikutnya. Sawah-sawah di Desa Pasireurih dapat dikelompokan dalam tiga jenis, yaitu sawah irigasi setengah teknis, sawah dengan irigasi sederhana, dan sawah tadah hujan.

Urutan data terbanyak berikutnya pada Tabel 2 adalah warga masyarakat yang bergerak di sektor usaha atau berwiraswasta. Sektor usaha yang ada di Desa Pasireurih adalah 298 home industry, 60 kios atau warung, lima wartel, dan satu Koperasi Simpan Pinjam. Kehadiran para wirausahawan di desa tersebut tentu dapat menghidupkan perekonomian di sana.
Warga masyarakat yang bergerak dalam bidang jasa juga cukup banyak, yaitu sekitar 125 orang. Salah satu di antara pekerjaan di bidang jasa yang cukup menarik minat warga adalah menjadi tukang ojeg. Peluang tersebut muncul karena tidak semua kampung yang ada di desa tersebut langsung terjangkau oleh kendaraan umum roda empat. Kesempatan ini pun akhirnya dimanfaatkan oleh para pemilik kendaraan roda dua untuk memberi jasa pelayanaan angkutan umum kepada mereka yang membutuhkannya.

Kategori terakhir adalah warga masyarakat yang bekerja di instansi pemerintahan, baik yang masih aktif maupun yang sudah pensiun. Tercatat di kantor desa sebanyak 100 orang pegawai negeri sipil, tujuh orang TNI, dan 25 orang pensiunan dari pegawai instansi pemerintah. Beberapa kantor pemerintahan yang ada di desa tersebut diantaranya adalah Pusat Kesehatan Masyarakat dan kantor desa.

Mata pencaharian seseorang akan terkait erat dengan latar belakang pendidikan yang dimilikinya. Meskipun tidak mutlak, pendidikan memberikan kontribusi yang cukup besar dalam menentukan jenis dan kualitas pekerjaan. Berkaitan hal tersebut, Tabel 3 berikut ini akan menampilkan data mengenai latar belakang pendidikan penduduk Desa pasireurih.

Tabel 3. Persentase Penduduk Desa Pasireurih berdasarkan Pendidikan
\begin{tabular}{|c|l|r|}
\hline No. & \multicolumn{1}{|c|}{ Jenjang Pendidikan } & Persentase \\
\hline 1. & Belum Sekolah & 79,55 \\
\hline 2. & Tidak Tamat Sekolah & 8,00 \\
\hline 3. & Tamat SD/ Sederajat & 1,96 \\
\hline 4. & Tamat SLTP/ Sederajat & 1,17 \\
\hline 5. & Tamat SLTA/ Sederajat & 0,98 \\
\hline 6. & Tamat Akademi & 0,19 \\
\hline 7. & Tamat Perguruan Tingoi & 0,31 \\
\hline 8. & Buta Huruf & 7,85 \\
\hline & Jumlah (\%) & 100,00 \\
\hline
\end{tabular}

Sumber: Monografi Desa Pasireurih, 2009

\section{Kehidupan Sosial Budaya}

Masyarakat Desa Pasireurih melakukan aktivitas domestik dan sosial seperti pekerjaan domestik dilakukan secara rutin berkaitan dengan aktivitas RT. Masyarakat Desa Pasireurih pun melakukan berbagai kegiatan lainnya untuk mengisi waktu luang yang ada dengan tujuan menggalang kebersamaan dan kerukunan antarwarga. Olahraga merupakan salah satu kegiatan masyarakat, khususnya kaum muda yang ada di desa tersebut. Sedangkan para ibu-ibu aktif dalam Pendidikan Kesejahteraan Keluarga (PKK) yang melakukan kegiatannya meliputi kegiatan pos pelayanan terpadu (Posyandu) dengan program rutinnya yaitu melakukan penimbangan bayi dan pelaksanaan kegiatan imunisasi yang dicanangkan oleh pemerintah.

Adapun untuk keamanan lingkungan, masyarakat membangun pos keamanan lingkungan (Pos Kamling). Sedikitnya ada 45 buah pos kamling di desa tersebut. Warga masyarakat sendiri secara bergilir mendapat tugas melakukan siskamling pada malam hari. Selain itu, ada juga masyarakat yang secara khusus diberi tugas

182 Prasetyo, Untung. et. al. Komodifikasi Upacara Tradisional Seren Taun dalam Pembentukan Identitas Komunitas 
khusus untuk menjaga keamanan lingkungan, dikenal dengan sebutan hansip (pertahanan sipil). Anggota hansip di desa tersebut berjumlah 15 orang.

Kerjasama antarwarga masyarakat Desa Pasireurih juga terjalin dalam berbagai kegiatan kemasyarakatan, seperti gotong royong memperbaiki jalan, membangun masjid, dan bersih-bersih lingkungan. Selain itu, warga juga bersama-sama melaksanakan berbagai aktivitas yang sifatnya menciptakan kegembiraan dan kebersamaan, misalnya kegiatan menyambut hari kemerdekaan dan upacara tradisional Seren Taun. Pelaksanaan upacara tradisional merupakan salah satu tradisi leluhur nenek moyang masyarakat Desa Pasireurih, khususnya di Kampung Budaya Sindangbarang. Masyarakat desa tersebut mayoritas adalah orang Sunda. Oleh karena itu kehidupan seharihari di tempat tersebut cukup kental dengan nuansa budaya Sunda, salah satunya diwujudkan dalam kegiatan Seren Taun.

\section{Upacara Tradisional Seren Taun di Kampung Budaya Sindangbarang}

\section{Sejarah Upacara Seren Taun di Kampung Budaya Sindangbarang}

Tepat di bawah kaki gunung Salak pada ketinggian 450 meter di atas permukaan laut di sebelah timur berbatasan dengan Sirnagalih; sebelah utara berbatasan dengan Parakan; sebelah barat berbatasan dengan Sirnasari; dan sebelah selatan berbatasan dengan Kabandungan terdapat beberapa bangunan rumah panggung yang seluruhnya terbuat dari bahan kayu. Letak rumah-rumah yang beratap injuk ini kira-kira 5 kilometer dari kota Bogor arah barat, tepatnya berada di Kampung Budaya Sindangbarang, Desa Pasireurih, Kabupaten Bogor. Seluruh bangunan rumah ini menyerupai bangunan rumah perkampungan adat di tatar Sunda. Dimana setiap bangunan rumah diperuntukan pada fungsinya yang berbeda-beda, misalnya balay, leuit, dan lain sebagainya.

Secara fisik tampak seluruh bangunan ini sengaja dibuat pada tahun 2007 atas prakarsa Bapak Maki Sumawijaya. Meskipun Bapak Entong Sumawijaya (kakek dari Bapak Maki Sumawijaya) bukanlah seorang keturunan sebagaimana digariskan dalam sistem kekerabatan orang Sunda dahulu, tetapi masyarakat setempat mempercayai kepemimpinannya, maka keberlanjutan upacara tradisional Seren Taun diteruskan oleh cucunya sampai sekarang. Dapat dipahami tujuan mendirikan perkampungan ini didasari oleh beberapa situs yang ditemukan di kompleks Sindangbarang, yaitu makam kuno dan benteng-benteng batu (Kota Batu); guci keramik (Desa Parakan); punden, dua pasang telapak kaki, batu-batu dakon, menhir, ceruk, batu bersisik, dan batu gores (alur sungai Ciangsana).

Upacara Seren Taun diselenggarakan kembali setelah upacara serupa terakhir kali digelar 35 tahun lalu, tepatnya 1971. Menurut sumber-sumber tertulis, yakni pantun Bogor, Seren Taun di Kampung Budaya Sindangbarang telah ada sejak zaman Kerajaan
Pajajaran. Upacara-upacara di Kerajaan Pajajaran ada yang bersifat tahunan (Seren Taun Guru Bumi) dan delapan tahunan (Seren Taun Tutug Galur).

Menurut beberapa kokolot (tokoh adat), Kerajaan Pajajaran hancur digempur Banten, Demak, dan Cirebon. Para pembesar di kerajaan tersebut banyak mengungsi ke wilayah Sukabumi Selatan. Ada yang terus menetap di sana tidak sedikit pula yang kembali ke kampung halamannya. Meskipun demikian, para pembesar itu tidak langsung kembali ke dalam kompleks bekas Pakuan. Mereka memilih mendirikan perkampungan di sekeliling benteng Pakuan. Selain itu, mereka juga tidak menggunakan nama asli sebagai para pembesar di Pakuan. Mereka memutuskan untuk menggunakan nama-nama baru. Hal tersebut dilakukan untuk menyesuaikan diri dengan statusnya yang baru sebagai warga masyarakat biasa. Meskipun demikian, kehidupan sosial budaya mereka tetap diwarnai tradisi Sunda Pajajaran yang agraris.

Tujuh belas tahun kemudian (diperkirakan tahun 1596), pasca keruntuhan kerajaan Pajajaran, salah satu tokoh yaitu Ki Murwa Alih melaksanakan upacara tradisional Seren Taun, yang menjadi sesepuh di wilayah Taman (sekarang menjadi kecamatan Tamansari). Namun setelah masuknya islam ke wilayah Sindangbarang, upacara tersebut tidak dilaksanakan seperti biasanya. Hal tersebut membawa dampak buruk bagi pertanian wilayah Sindangbarang, yaitu membuat hasil panen banyak yang gagal. Berdasarkan hal tersebut, Embah Jamaka (tokoh yang membawa islam ke Sindangbarang) berpendapat bahwa harus diadakan kembali upacara Seren Taun apabila menginginkan hasil panen baik kembali. Namun upacara tersebut harus dalam format yang berbeda, yaitu waktunya pada bulan Muharram dengan ada tambahan upacara sedekah bumi.

Latar belakang dilaksanakannya upacara Seren Taun, ketika itu masyarakat Sindangbarang dan sekitarnya kehidupannya dalam kondisi di bawah garis kemiskinan. Menurut sesepuh setempat, dapat digambarkan kondisinya bisa dikatakan dahar isuk sore heunteu (bila pagi makan, sorenya tidak makan). Hal tersebut menggambarkan bahwa masyarakat setempat pada waktu itu hidupnya sangat memprihatinkan. Kehidupan seperti itu bukan hanya di Kampung Sindangbarang, akan tetapi di daerah sekitarnya pun demikian.

Berdasarkan hal tersebut, maka untuk memperbaiki kehidupan masyarakat setempat, Mama Hajji Abdullah mengajak warga masyarakat setempat untuk mengadakan upacara yang bersifat ritual. Dengan melaksanakan upacara, diharapkan akan mendapatkan hasil bumi (padi) yang lebih banyak dari masa-masa sebelumnya. Sejak saat itu, upacara Seren Taun dilaksanakan setiap tahunnya dan diwariskan kepada generasi penerusnya yaitu M.H. Ali, lalu ke Mama H. Abdullah. Warga Kampung Sindangbarang, Cibeureum, Kuta Batu, dan Tamansari memang telah pareuman obor kepada karuhun mereka. Meskipun demikian, tinggalan pranata budaya karuhun-nya masih melekat dan terpelihara dalam keseharian mereka, yaitu salah satunya tercermin dalam tradisi tahunan sedekah bumi 
yang dilaksanakan oleh kelompok-kelompok tertentu dalam kurun waktu yang tidak bersamaan.

Berdasarkan hal tersebut, dikaitkan dengan kesadaran pribadi warga masyarakat, maka upacara sedekah bumi yang acak diupayakan ditata kembali menjadi kegiatan kelompok dalam genre gelaran sekarang dengan tetap merujuk pada upacara Seren Taun guru bumi sebagaimana kini masih tetap dijalankan di beberapa kelompok masyarakat keturunan Sunda Pajajaran lainnya. Upacara Seren Taun yang semula dilaksanakan oleh Mama Hajji Abdullah dilanjutkan oleh Haji Ahmad, lalu diteruskan oleh Bapak Lurah Jali, dan terakhir oleh Bapak Entong Sumawijaya. Setelah itu upacara Seren Taun tidak dilaksanakan hingga pada tahun 2006 dilaksanakan kembali oleh Bapak Maki Sumawijaya.

\section{Nilai-nilai Sosial yang Terkandung dalam Upacara Seren Taun}

Upacara Seren Taun yang dilaksanakan oleh masyarakat Sindangbarang bertujun untuk:

1. Dengan dilaksanakannya upacara Seren Taun, diharapkan hasil bumi para petani Kampung Budaya Sindangbarang pada tahun yang akan datang lebih meningkat dari tahun sebelumnya. Perwujudan tujuan tersebut, agar masyarakat Sindangbarang dan sekitarnya di dalam tatanen-nya mendapatkan hasil yang melimpah. Sehingga masyarakat tidak kekurangan baik sandang maupun pangan atau dalam bahasa Sunda diistilahkan "bru di juru bro di panto ngalayah di tengah imah". Selain itu, dalam beberapa nasehat Sunda dikatakan bahwa "usik diusikeun malik dimalikeun kersaning Gusti Maha Suci”, maksudnya adalah agar hidup tidak selalu kekurangan haruslah selalu ingat kepada Sang Pencipta dengan jalan beribadah, berdoa, menjalankan perintah-Nya serta menjauhi laranganNya. Melalui penyelenggaraan upacara Seren Taun diharapkan agar pemangku roda pemerintahan di Kampung Sindangbarang dapat menjalankan tugasnya dengan penuh bijaksana. Demikian pula halnya dengan segala peraturan yang telah ditetapkan oleh pemerintah agar dijalankan secara konsekwen.

2. Upacara Seren Taun adalah sarana untuk menjalin silahturahmi ukhuwah islamiyah dan melestarikan ikatan kekeluargaan keturunan Sindangbarang dan sekitarnya. Selain itu, upacara tradisional Seren Taun memegang peranan penting dalam mempromosikan pariwisata yang sedang dibina oleh Pemerintah Daerah Kabupaten Bogor. Upacara tersebut merupakan kegiatan yang melibatkan seluruh masyarakat Sindangbarang dan sekitarnya dalam rangkaian pesta tiga hari empat malam dengan berbagai kegiatan seperti pengajian dan kegiatan tradisional.

\section{Makna yang Terkandung dalam Upacara Tradisional Seren Taun}

Beberapa makna yang terkandung dalam simbol-simbol upacara Seren Taun yang dilaksanakan oleh masyarakat Sindangbarang, sebagai berikut:

1. Baju kampret hitam putih adalah lambang masyarakat petani ladang. Hitam melambangkan guru Bumi, putih melambangkan Dewi Rumbiyang Jati.

2. Kain pembungkus pare ambu (padi ibu) berwarna putih melambangkan Dewi Rumbiyang Jati, dan kain pembungkus pare ayah berwarna hitam melambangkan Guru Bumi yang keduanya dikawinkan dalam leuit.

3. Pohon hanjuang melambangkan dunia atas (gaib), sebagai perantara kehadiran para karuhun kampung Sindangbarang.

4. Kendi besar (cai kakulu) yaitu air dari 7 mata air yang melambangkan kehidupan dengan tiap airnya memiliki manfaat yang berbeda.

5. Parukuyan (berisi arang dan kemenyan) adalah alat untuk menyampaikan doa. Kemenyan yang dibakar dalam parukuyan akan mengeluarkan kepulan asap yang membumbung ke atas dan mengeluarkan bau yang khas dan harum. Menurut kepercayaan sesepuh terdahulu, kepulan asap tersebut melambangkan komunikasi antara manusia yang ada "di bawah" dan penguasa yang ada "di atas". Bau harum kemenyan menandakan penghormatan pada penguasa alam dan warna hitam dari arang melambangkan kesejukan serta kesetiaan. Hal tersebut menandakan bahwa warga masyarakat dan pendukung upacara masih setia menjalankan perintah adat yang diwariskan oleh leluhurnya.

6. Tujuh macam rujak dari buah-buahan yang dijadikan sesajen merupakan simbol bilangan, yaitu tujuh melambangkan jumlah hari atau dalam satu minggu ada tujuh hari.

7. Kerbau yang disembelih pada waktu upacara melambangkan satu filosofi hidup. Penyembelihan kerbau dimaksudkan untuk membuang "kesalahan" yang ada pada diri manusia. Kain putih di atas kerbau, melambangkan kesucian atau kebersihan hati manusia.

8. Menyimpan padi di Leuit Ratna Inten, mengandung makna bahwa manusia harus dapat menyisihkan padi untuk disimpan sebagai tabungan agar hidup tidak kekurangan.

9. Buah kelapa muda (dawegan) merupakan lambang dunia gaib yang tidak nampak (dunia di atas).

\section{Rangkaian Upacara Tradisional Seren Taun}

a. Tempat dan waktu penyelenggaraan

Tempat pelaksanaan upacara tradisional Seren Taun dipusatkan di Kampung Budaya Sindangbarang. Upacara tradisional Seren Taun di Sindangbarang 
dilaksanakan setiap satu tahun sekali, tepatnya pada awal tahun hijriyah. Pelaksanaan upacara Seren Taun yang dianggap paling baik yakni pada awal tahun hijriyah, mulai pada tanggal 1 sampai tanggal 15. Pada tanggal tersebut bulan akan mulai naik, tepatnya mulai tanggal 14-15, yang dalam bahasa Sunda dikatakan "caang bulan opat belas" dimana pada masyarakat dahulu dilaksanakan acara ngabungbang.

Maksud pelaksanaan upacara pada awal tahun hijriyah, yakni untuk memohon kepada Allah SWT agar hati kita bersih dari sifat jail-kaniaya (sifat- sifat buruk). Selain itu, harapan utamanya semoga Allah SWT mengabulkan doa kita agar selamat di dunia dan akhirat. Hidup kita penuh berkah dan ridhonya, sehingga bisa hidup sejahtera baik lahir maupun batin. Tempat pelaksanaan upacara tradisional Seren Taun dipusatkan di Kampung Budaya Sindangbarang.

\section{b. Teknis penyelenggaraan}

Sekitar satu bulan atau lebih menjelang pelaksanaan upacara Seren Taun, terlebih dahulu diadakan musyawarah ponggokan. Dalam acara tersebut berkumpul keluarga besar Bapak Maki Sumawijaya, seluruh pini sepuh perwakilan dari setiap kampung atau desa, dan aparat pemerintah setempat. Masalah yang dibahas dalam ponggokan sebagai berikut:

\section{Menentukan hari pelaksanaan upacara}

2. Menyusun anggaran atau dana yang diperlukan untuk acara

3. Membentuk panitia upacara yang tersusun sebagai berikut: Pelindung (Kepala Dinas Kebudayaan dan Pariwisata, Kabupaten Bogor dan Camat Tamansari), penasehat, ketua umum, ketua pelaksana, sekretaris, bendahara, seksi-seksi (upacara protokol, pengajian, kesenian, keamanan, konsumsi, humas atau publikasi, perlengkapan upacara, penerima tamu, dan dokumentasi)

Pihak-pihak yang terlibat dalam upacara, yaitu seluruh lapisan masyarakat Sindangbarang dan sekitarnya dan bahkan sampai keluar Kecamatan Tamansari. Lapisan masyarakat yang terlibat mengandung arti menyaksikan upacara tidak memandang status sosial, usia, dan jenis kelamin. Adapun peserta yang terlibat langsung sebagai pelaku diantaranya pupuhu (ketua adat) beserta ema (istri ketua adat), juru rajah, tujuh orang mojang pembawa kendi air dari tujuh sumber mata air, 16 orang pembawa rengkong, empat orang pembawa pohon hanjuang, dua orang pembawa pohon tebu, lima orang ibu-ibu pemain tutunggulan, dan para sesepuh.

\section{c. Jalannya upacara}

Sebelum upacara Seren Taun dilaksanakan, dipersiapkan segala perlengkapan yang diperlukan untuk upacara, diantaranya:

1. Busana: baju kampret warna putih dan hitam, iket totopong kepala, dan baju semacam kebaya warna merah dan putih. Baju kampret putih dan iket kepala akan dikenakan oleh ketua adat (рupuhu), para sesepuh, tamu undangan, dan panitia. Baju kampret hitam dan iket kepala dipakai oleh peserta upacara yang membawa rengkong, grup kesenian tradisional, prajurit dan pengawal kerajaan, pembawa tandu, dan dong dang. Kebaya berwarna merah putih dipakai oleh 7 orang mojang yang membawa kendi yang didalamnya berisi air dari 7 wulu wotan (sumber mata air).

2. Leuit Ratna Inten, untuk menyimpan pare ambu (padi ibu) dan pare ayah (padi ayah) serta padi lainnya.

3. Lesung, untuk nutu pare (menumbuk padi) dengan memakai halu (tongkat kayu).

4. Jampana, tempat menyimpan pare ambu, pare ayah, berbagai jenis kue, hasil tanaman, buahbuahan, dan nasi tumpeng.

5. Cempeh (nyiru leutik), tempat meyimpan sesajen dan aneka macam makanan khas daerah setempat.

6. Kendi, terdiri dari tujuh buah untuk menyimpan air dari tujuh wulu wotan (sumber mata air) dan kendi besar satu buah untuk menyimpan air dari tujuh sumber mata air.

7. Payung, terdiri dari dua buah payung berwarna putih dan hitam. Payung putih digunakan untuk memayungi hasil bumi, sedangkan payung hitam untuk memayungi pare ambu dan pare ayah.

8. Pohon hanjuang, pohon ini berjumlah tiga buah, terdiri dari satu buah disimpan di kendi yang besar dan dua buah dibawa oleh peserta upacara.

9. Dua buah pohon tebu, dibawa oleh dua orang.

10. Rengkong 16 buah, untuk membawa padi hasil panen.

11. Satu ekor kerbau, yang digunakan untuk disembelih.

12. Kesenian tradisional, untuk menghibur dan mengiringi jalannya upacara.

13. Panggung, terdiri dari tiga buah panggung untuk pertunjukkan kesenian.

14. Obor, untuk nyaangan jalan.

15. Sesajen, disediakan oleh penyelenggara upacara untuk persembahan para leluhur.

Ritual Seren Taun Kampung Budaya Sindangbarang biasanya dilaksanakan pada bulan Muharam yang dilakukan selama tujuh hari rangkaian acara, yaitu:

1. Hari pertama diadakan upacara Neutepkeun, yaitu ritual yang dilaksanakan di tempat pabeasan (tempat menyimpan beras di Imah Gede). Di pabeasan semua bahan-bahan makanan yang akan dimasak dikumpulkan. Kokolot akan memimpin doa kepada Allah SWT dan menetapkan niat untuk memulai acara Seren Taun serta memohon agar kebutuhan untuk konsumsi selama penyelenggaraan acara tidak mengalami kekurangan.

2. Hari kedua diadakan acara Ngembang, yaitu ziarah ke makam leluhur warga Sindangbarang yang letaknya di Gunung Salak. Makam yang diziarahi 
adalah makam Sang Prabu Langlangbuana Prabu Prenggong Jayadikusumah. Acara tersebut dipimpin oleh kokolot, panggiwa dan panengen.

3. Hari ketiga adalah Sawer Sudat dan Ngalage, yaitu upacara sudat (sunat) menurut tradisi budaya Bogor yaitu mengarak pengantin sunat.

4. Hari keempat dilaksanakan Sebret Kasep, yaitu pelaksanaan sudat (sunat) itu sendiri, khitanan massal yang dilakukan tidak boleh lebih dari pukul 14.30 WIB. Hal ini dikarenakan pukul 15.00 WIB akan dilakukan Ngunday yaitu marak lauk (mengambil ikan) di sungai.

5. Hari kelima dilaksanakan Ngukuluan, yaitu tugas kepada kokolot dan parawari untuk memulai menyiapkan tujuh kendi untuk mengambil air dari tujuh sumber mata air, yaitu Cipamali, Cimaeja, Cimalipah, Cikubang, Sumur Jalatunda, Ciputri, dan Cieming. Setelah dilakukan pengambilan dari ketujuh mata air tersebut kemudian tujuh kendi tersebut disatukan di tempayan yang dibungkus oleh kain putih dan hitam. Ketujuh sumber mata air yang diambil dalam proses ritual Seren Taun dikelola oleh masyarakat lokal.

6. Hari keenam barulah disiapkan acara Ngijabkeun (menyebut nama-nama leluhur yang sudah tiada), Sedekah kue (sebanyak 40 tampah kue disediakan dihadapan warga dan kokolot), Helaran (pawai), Nugel Munding (ngarak kerbau), Sedekah daging, dan pertunjukan seni. Pertama dibacakan riwayat kampung dan doa, setelah itu kue diperebutkan. Setelah itu dilakukan helaran dengan mengarak tumpeng dan diiringi awalan angklung gubrag, tujuh orang mojang, pembawa pohon hanjuang, jampana berisi air kukulu, pembawa tebu hitam, pembawa jampana daging, pembawa pohon hanjuang, para kokolot, kesenian reog, calung, kendang pencak diikuti oleh warga masyarakat menuju lapangan SD Inpres untuk memotong kerbau. Daging kerbau yang dipotong kemudian dimasak dan diperebutkan oleh masyarakat. Malam harinya dihadirkan pertunjukan seni di dua buah panggung. Yang satu di alun-alun kajeroan dan satu lagi di lapangan.

7. Hari ketujuh merupakan hari puncak yaitu pelaksanaan Helaran Majiekeun Pare (menyimpan padi ke dalam leuit) dan Helaran Dongdang (ngarak dongdang). Ngarak Dongdang dimulai dari Imah Kolot yang jaraknya satu kilometer dari kawasan Kampung Budaya Sindangbarang. Warga dengan berpakaian adat (baju putih, celana hitam, dan ikat kepala hitam putih) dengan riang mempersiapkan dan membawa aneka hasil bumi untuk diarak bersama pembawa Rengkong (padi) hasil panen, para kokolot dan rombongan kesenian, juga warga lainnya. Dongdang yang telah dipersiapkan, sebelum berangkat didoakan terlebih dahulu. Seorang sesepuh memimpin doa tersebut sambil menyipratkan air dari kendi yang berisi air dari tujuh mata air (Kukulu) pada rombongan dan warga. Pukul 08.30 rombongan helaran segera bergerak menuju Kampung Budaya Sindangbarang untuk melakukan upacara Majiekeun Pare ayah dan ambu ke dalam Lumbung Ratna Inten. Di lapangan, tepatnya di halaman Imah Gede, sang Rama sudah menunggu untuk melakukan prosesi upacara adat memasukkan padi. Kemudian setelah selesai memasukkan padi sang Rama memberi pesan-pesan kepada warga yang hadir. Dongdang pun segera dibawa kedepan. Setelah didoakan oleh sang Rama Dongdang langsung diperebutkan oleh warga dan pengunjung. Warga dan pengunjung itu langsung menyerbu jajaran tandu yang berisi aneka buah-buahan dan sayur-sayuran. Setelah tuntas memperebutkan Dongdang, warga dihibur dengan pertunjukan tari yang diiringi oleh gamelan. Secara atraktif 50 mudamudi Sindangbarang mempertunjukkan keahlian mereka, disusul Gondang, Angklung Gubrag, Kendang Penca dan diakhiri dengan Rampak Parebut Seeng. Seluruh rangkaian acara puncak tersebut diikuti oleh sesepuh Kampung Budaya Sindangbarang, pejabat Provinsi Jawa Barat dan Muspida Kabupaten Bogor bersama tamu undangan lainnya. Malam harinya di Imah Gede, para kokolot dan Sang Rama berkumpul untuk menceritakan sejarah perjalanan Sindangbarang dari zaman Kerajaan Pajajaran hingga kini. Di alun-alun Kajeroan pagelaran wayang golek semalam suntuk digelar.

\section{Pantangan-pantangan yang Harus Ditaati}

Pantangan atau tabu masih digunakan oleh masyarakat Kampung Budaya Sindangbarang dengan memegang teguh adat istiadat nenek moyang atau leluhurnya. Setiap upacara yang sifatnya sakral biasanya memiliki pantangan-pantangan atau tabu-tabu yang harus ditaati atau dipatuhi. Jika pantangan dilanggar, akan mendapatkan musibah baik pada diri seseorang maupun pada kelompok.

Pantangan atau tabu-tabu yang berlaku di Kampung Budaya Sindangbarang munculnya dikarenakan dahulu belum ada seperangkat hukum atau undang-undang yang mengatur tatanan kehidupan sehari-hari. Oleh karena itu, pantangan-pantangan dijadikan dasar seperangkat hukum atau undang-undang untuk mengatur dan mengontrol tatanan kehidupan yang harus dipatuhi oleh semua warga. Pantangan atau tabu pada upacara Seren Taun yang harus ditaati adalah tidak boleh ada yang bersuara pada saat pembacaan rajah. Semua bunyi-bunyian harus berhenti dan para peserta upacara, tamu undangan, penonton di sekitarnya harus duduk dan tidak boleh ribut. Hal ini dimaksudkan agar tidak mengganggu konsentrasi juru rajah yang sedang berdoa dan melakukan kontak dengan penguasa alam. Selain itu, sesajen harus lengkap untuk menandakan rasa hormat dan terima kasih mereka kepada Dewi Sri.

\section{HASIL DAN PEMBAHASAN}

\section{Hubungan Komodifikasi Upacara Tradisional Seren Taun dengan Motif Melaksanakan Upacara Tradisional Seren Taun Warga Kampung Budaya Sindangbarang}

Penyajian data dimulai dengan mendeskripsikan variabel yang akan diuji hubungan kausalnya. Deskripsi

186 | Prasetyo, Untung. et. al. Komodifikasi Upacara Tradisional Seren Taun dalam Pembentukan Identitas Komunitas 
variabel motif melaksanakan upacara tradisional Seren Taun bertujuan untuk memberikan gambaran tentang motif melaksanakan upacara tradisional Seren Taun warga Kampung Budaya Sindangbarang. Setelah setiap variabel yang akan diuji dideskripsikan, maka penyajian data berikutnya adalah penjelasan mengenai hubungan antara komodifikasi upacara tradisional Seren Taun dengan motif melaksanakan upacara tradisional Seren Taun dalam pembentukan identitas komunitas.

Secara umum motif melaksanakan upacara tradisional Seren Taun warga Kampung Budaya Sindangbarang cukup tinggi, yaitu sebesar 86,6 persen (Tabel 4). Angka ini menunjukan bahwa ketika melaksanakan upacara tradisional Seren Taun, tiap individu memiliki motif yang tinggi. Warga Kampung Budaya Sindangbarang memiliki alasan-alasan yang kuat untuk melaksanakan upacara tradisional Seren Taun.

Tabel 4. Jumlah dan Persentase Pelaku Upacara Seren Taun menurut Motif Melaksanakan Upacara Seren Taum

\begin{tabular}{|l|r|r|}
\hline Motif Melaksanakan Upacara Seren Taun & \multicolumn{1}{|c|}{$\begin{array}{c}\text { Frekuensi } \\
\text { (orang) }\end{array}$} & \multicolumn{2}{|c|}{$\begin{array}{c}\text { Persentase } \\
(\%)\end{array}$} \\
\hline Rendah & 2 & 6,7 \\
\hline Sedang & 2 & 6,7 \\
\hline Tinggi & 26 & 86,6 \\
\hline Total & 30 & 100,0 \\
\hline
\end{tabular}

Tabel 5 memperlihatkan bahwa warga Kampung Budaya Sindangbarang memiliki rasa syukur yang tinggi terhadap melimpahnya hasil panen, baik yang sekarang didapatkannya maupun panen yang akan datang, yaitu sebesar 96,7 persen. Hal tersebut dikarenakan dalam konteks kehidupan tradisi masyarakat peladang Sunda, Seren Taun merupakan wahana untuk bersyukur kepada Tuhan Yang Maha Esa atas segala hasil pertanian yang dilaksanakan pada tahun ini, serta berharap hasil pertanian mereka akan meningkat pada tahun yang akan datang yang diaktualisasikan dengan menyimpan padi di dalam lumbung (leuit).

Tabel 5. Jumlah dan Persentase Pelaku Upacara Seren Taun menurut Motif Melaksanakan Upacara Seren Taum berdasarkan Rasa Syukur

\begin{tabular}{|l|r|r|}
\hline \multicolumn{1}{|c|}{ Tingkat Motif } & Frekuensi (orang) & Persentase (\%) \\
\hline Rendah & 1 & 3,3 \\
\hline Sedang & 0 & 0 \\
\hline Tinggi & 29 & 96,7 \\
\hline Total & 30 & 100,0 \\
\hline
\end{tabular}

Berdasarkan hal tersebut, dapat dijelaskan bahwa pelaksanaan upacara tradisional Seren Taun merupakan representasi kehidupan masyarakat pertanian yang mandiri akan kebutuhan pangan. Hal tersebut dibuktikan dengan adanya tujuan khusus pelaksanaan upacara tradisional Seren Taun, yaitu upacara tradisional Seren Taun ditujukan agar warga Kampung Budaya Sindangbarang mendapatkan hasil yang melimpah, sehingga tidak kekurangan baik sandang maupun pangan atau yang diistilahkan oleh pupuhu Kampung Budaya Sindangbarang yaitu "bru di juru bro di panto ngalayah di tengah imah" (banyak di pojok, banyak di pintu, penuh di dalam rumah).
Tabel 6. Jumlah dan Persentase Pelaku Upacara Seren Taun menunut Motif Melaksanakan Upacara Seren Taun berdasarkan Pemeliharaan Kelembagaan Komunitas

\begin{tabular}{|l|r|r|}
\hline \multicolumn{1}{|c|}{ Tingkat Motif } & Frekuensi (orang) & Persentase (\%) \\
\hline Rendah & 1 & 3,3 \\
\hline Sedang & 0 & 0 \\
\hline Tinggi & 29 & 96,7 \\
\hline Total & 30 & 100,0 \\
\hline
\end{tabular}

Tabel 6 memperlihatkan bahwa warga Kampung Budaya Sindangbarang memiliki rasa pemeliharaan kelembagaan komunitas yang tinggi yaitu sebesar 96,7 persen. Upacara tradisonal Seren Taun Kampung Budaya Sindangbarang mengajarkan makna gotongroyong, kepedulian terhadap sesama warga, dan menghormati sosok Dewi Kesuburan. Makna gotong royong yang digambarkan dalam tiap prosesi upacara Seren Taun sangat melekat dalam kehidupan sehari-hari warga Kampung Budaya Sindangbarang, maka wajar saja apabila upacara Seren Taun merupakan upacara yang hingga kini dijaga ke-sakralan-nya.

Diketahui dalam beberapa kesempatan wawancara terbuka dengan para warga Kampung Budaya Sindangbarang, dapat dicontohkan ketika salah seorang warga mendapat musibah atau papait, mereka membantu dengan sukarela tanpa melihat latar belakang apa pun. Hal tersebut sesuai dengan upacara tradisional Seren Taun yang meniadakan jurang pemisah antar masyarakat. Dalam hal kepedulian terhadap sesama, Bapak Ukat menjelaskan bahwa upacara Seren Taun adalah gambaran warga Desa Pasireurih dan Kampung Budaya Sindangbarang yang penuh rasa kekeluargaan dan dedikasi yang tinggi antarsesama warga.

\begin{tabular}{|c|c|c|}
\hline Tingkat Motif & Frekuensi (orang) & Persentase (\%) \\
\hline Rendah & 1 & 3,3 \\
\hline Sedang & 2 & 6,7 \\
\hline Tinggi & 27 & 90,0 \\
\hline Total & 30 & 100,0 \\
\hline
\end{tabular}

Selanjutnya pada Tabel 7 memperlihatkan bahwa warga Kampung Budaya Sindangbarang memiliki lambang kesucian hati manusia yang tinggi, yaitu sebesar 90,0 persen. Hal tersebut menjelaskan bahwa upacara tradisional Seren Taun Kampung Budaya Sindangbarang digelar dalam rangka menghormati $N y i$ Pohaci atau Nyi Sri Rumbyang, atau Dewi Kesuburan untuk menjaga keseimbangan antara manusia dengan alamnya. Hal ini senada dengan Effendy dan Anoegrajekti (2004) berpendapat bahwa satu sisi penting yang harus dilihat dalam mitos Dewi Sri, padi, dan kesuburan adalah proses reproduksi yang mengindahkan keseimbangan dan keteraturan saling menguntungkan baik yang menyangkut hubungannya dengan alam. Pelestarian reproduksi padi yang seimbang dan teratur atas "naungan" Dewi Sri, dalam upacara Seren Taun, dipahami akan menjamin terwujudnya kesejahteraan dan keberlangsungan, 
sebagaimana pelestarian reproduksi manusia yang menjaga kesinambungan kehidupan.

\begin{tabular}{|c|c|c|}
\hline Tingkat Motif & Frekuensi (orang) & Persentase (\%) \\
\hline Rendah & 1 & 3,3 \\
\hline Sedang & 0 & 0 \\
\hline Tinggi & 29 & 96,7 \\
\hline Total & 30 & 100,0 \\
\hline
\end{tabular}

Tabel 8 memperlihatkan bahwa warga Kampung Budaya Sindangbarang memiliki keinginan untuk melestarikan kesenian tradisional Sunda yang tinggi, yaitu sebesar 96,7 persen. Hal tersebut dapat dijelaskan bahwa secara umum upacara tradisional Seren Taun merupakan upaya warga Kampung Budaya Sindangbarang untuk melestarikan kesenian tradisional Sunda. Hal ini diungkapkan oleh salah satu panggiwa Kampung Budaya Sindangbarang, Bapak Aseng menjelaskan bahwa pelaksanaan upacara tradisional Seren Taun dapat dijadikan upaya pelestarian kesenian tradisional Sunda yang pada akhir-akhir ini sangat ditinggalkan oleh sebagian orang, khususnya para remaja yang pada zaman sekarang ini lebih menyukai kebudayaan Barat. Sebagaimana dikutip sebagai berikut:

"Dengan adanya Seren Taun di Kampung Budaya Sindangbarang diharapkan remaja-remaja, khusunya anak-anak dapat lebih bisa mengetahui secara jelas bahwa kesenian dan kebudayaan daerahnya sendiri tidak kalah menarik dan bagus untuk dipelajari dan diketahui".

Hipotesis awal menyatakan bahwa semakin tinggi proses komodifikasi upacara tradisional Seren Taun maka akan semakin rendah motif melaksanakan upacara tradisional Seren Taun, maupun sebaliknya. Agar dapat melihat hubungan keduanya, maka dilakukan uji hubungan dengan menggunakan tabulasi silang dan analisis pearson's. Pengambilan keputusan berdasarkan nilai signifikansi (Approx. Sig.), jika Approx. Sig. lebih besar dari $\alpha(0,05)$ maka Ho diterima, artinya tidak terdapat hubungan antara variabel-variabel yang diuji.

Tabel 9. Persentase Pelaku Upacara Seren Taun menurut Komodifikasi Upacara Seren Taun dan Motif Melaksanakan Upacara Seren Taun

\begin{tabular}{|l|r|r|r|}
\hline \multirow{2}{*}{$\begin{array}{c}\text { Motif Melaksanakan Upacara } \\
\text { Seren Taun }\end{array}$} & \multicolumn{3}{|c|}{$\begin{array}{c}\text { Komodifikasi Upacara } \\
\text { Seren Taun (\%) }\end{array}$} \\
\cline { 2 - 5 } & Rendah & Sedang & \multicolumn{1}{c|}{ Tinggi } \\
\hline Rendah & 0 & 100,0 & 50,0 \\
\hline Sedang & 3,3 & 0 & 50,0 \\
\hline Tinggi & 86,7 & 0 & 0 \\
\hline Total & 100,0 & 100,0 & 100,0 \\
\hline
\end{tabular}

Kampung Budaya Sindangbarang merupakan rekonstruksi cara-cara kehidupan masyarakat tradisional Sunda. Apabila diperhatikan lebih jauh, maka akan ditemukan berbagai keunikan di Kampung Budaya Sindangbarang. Hal tersebut dimulai dari tinggal bersama kokolot, para seniman Sunda, hingga akan ditemukan ibu-ibu yang menumbuk padi di saung lisung, memasak dengan kayu bakar dalam hawu, melihat para petani bercocok tanam, dan belajar kesenian tradisional Sunda. Berdasarkan hal tersebut, tidak dapat dipungkiri bahwa Kampung Budaya Sindangbarang merupakan salah satu alternatif tempat wisata yang memberikan berbagai pilihan wisata dengan suasana kehidupan masyarakat agraris tradisional Sunda.

Berdasarkan uraian tersebut, ada beberapa tujuan yang ingin dicapai oleh beberapa pihak dengan adanya upacara tradisional Seren Taun di Kampung Budaya Sindangbarang, yaitu menjadikan upacara tradisional Seren Taun sebagai penambah devisa daerah. Desa Pasireurih merupakan desa penghasil sandal dan ini menguntungkan bagi pemerintah setempat. Selain mengurangi tingkat pengangguran, juga meningkatkan ekonomi rakyat. Ditambah lagi dalam hal yang menyangkut kebudayaan, seperti adanya upacara Seren Taun. Apabila tepat dalam pengelolaannya, akan memberi keuntungan berlipat, yaitu pertama, upacara Seren Taun dapat diagendakan menjadi objek wisata budaya. Wisata budaya ini akan menarik banyak pengunjung, baik dari dalam maupun luar kota. Kedatangan mereka berpotensi untuk mengangkat ekonomi rakyat. Pemasaran produk setempat, seperti sandal, bisa meluas. Kedua, Desa Pasiruerih menjadi lebih dikenal secara luas. Hal ini berpotensi mengangkat nama pemerintah desa setempat khususnya, dan umumnya Kabupaten Bogor. Ketiga, upacara Seren Taun menjadikan Desa Pasireurih kondusif untuk meningkatkan pembangunan.

Hasil wawancara dengan beberapa aparatur pemerintah desa, yaitu Bapak Lurah Desa Pasiruerih, diketahui bahwa upacara tradisional Seren Taun merupakan suatu kegiatan sosial yang memiliki daya tarik tersendiri. Oleh karena itu, upacara tradisional Seren Taun dapat diberdayakan sebagai salah satu aspek pariwisata daerah, dalam hal ini pariwisata budaya. Sebagaimana dikutip sebagai berikut:
"Seren Taun di Kampung Budaya Sindangbarang diharapkan didatangi para turis-turis mancanegara yang notabene lebih menyukai kebudayaan dan seni yang alami dapat tertarik minatnya untuk berwisata ke Kampung Budaya Sindangbarang, karena hal tersebut dapat menambah devisa bagi warga sekitar".

Selanjutnya dijelaskan bahwa:
"Kampung Budaya Sindangbarang ini bisa menjadi penambah aset dan devisa bagi warga sekitar, khususnya pemerintah Kabupaten Bogor. Karena dengan adanya Kampung Budaya ini, turis-turis yang memang tertarik akan kesenian dan kebudayaan akan berdatangan dengan sendirinya untuk melihat dan menyaksikan langsung kesenian yang ada di bogor". 
Tabel 9 menunjukan bahwa 86,7 persen warga Kampung Budaya Sindangbarang yang memiliki kecenderungan yang rendah terhadap komodifikasi upacara tradisional Seren Taun. Dalam Tabel 9 secara umum terlihat bahwa semakin rendah proses komodifikasi upacara tradisional Seren Taun yang terjadi maka semakin tinggi motif melaksanakan upacara tradisional Seren Taun. Hal tersebut berarti ada hubungan antara proses komodifikasi upacara tradisional Seren Taun dengan motif melaksanakan upacara tradisional Seren Taun, yaitu semakin rendah proses komodifikasi maka semakin tinggi motif melaksanakan upacara tradisional Seren Taun. Hal ini menunjukan bahwa warga Kampung Budaya Sindangbarang tetap melihat upacara tradisional Seren Taun sebagai kegiatan yang mengaktualisasikan keyakinan mereka terhadap kekuasaan Tuhan Yang Maha Kuasa. Upacara tradisional Seren Taun bagi warga Kampung Budaya Sindangbarang merupakan ekspresi rasa syukur mereka terhadap hasil bumi yang telah didapatkannya serta harapannya untuk kelimpahan hasil bumi di tahun berikutnya.

Secara umum warga yang memiliki kecenderungan yang tinggi terhadap proses komodifikasi upacara tradisional Seren Taun merupakan warga yang menjajakan berbagai barang kesenian Sunda dan berbagai barang home industry warga Kampung Budaya Sindangbarang. Warga Kampung Sindangbarang secara umum melihat ataupun memandang upacara tradisional Seren Taun bukan sekedar kegiatan yang dilakukan hanya untuk keperluan hiburan untuk menghibur para wisatawan, keperluan "tontonan" di Kampung Budaya Sindangbarang, ataupun pemenuhan pendapatan daerah melalui pariwisatanya. Melainkan upacara tradisional Seren Taun dipandang sebagai suatu hal yang sangat sakral, yang didalamnya terdapat berbagai makna.

Berdasarkan data-data yang didapatkan dari kuesioner dan hasil wawancara, dapat dijelaskan bahwa proses komodifikasi upacara tradisional Seren Taun memiliki kecenderungan yang rendah terhadap motif melaksanakan upacara tradisional Seren Taun. Dapat dikatakan bahwa proses komodifikasi upacara tradisional Seren Taun merupakan program atau rencana pemerintah untuk meningkatkan kesejahteraan kehidupan warga setempat dalam kerangka memajukan pariwisata dan kebudayaan tradisional, dalam hal ini Kampung Budaya Sindangbarang merupakan modal bagi pemerintah daerah untuk "meluruskan" program tersebut. Upacara tradisional Seren Taun merupakan salah satu kegiatan tradisional yang dapat menjadi daya tarik para wisatawan, sebagaimana yang diungkapkan oleh pupuhu, Bapak Achmad Maki Sumawijaya, yaitu:

"setelah terputus lebih dari 32 tahun, tradisi adat yang menjadi daya tarik wisata kini mulai rutin digelar, di antaranya Seren Taun yang telah digelar untuk keempat kalinya".

Surbakti (2009) berpendapat bahwa komodifikasi adalah proses yang diasosiasikan dengan kapitalisme dimana objek, kualitas, dan simbol dijadikan sebagai komoditas yang tujuan utamanya adalah untuk dijual. Selanjutnya Surbakti (2009) menjelaskan bahwa komodifikasi kebudayaan, dalam hal ini adalah upacara tradisional Seren Taun, merupakan kombinasi kekuatan pemerintah dan pengusaha. Hal tersebut mengandung arti bahwa proses komodifikasi terjadi akibat adanya campur tangan pemerintah yang mengembangkan dan melestarikan upacara tradisional Seren Taun sebagai modal pengembangan devisa pemerintah daerah melalui program pariwisatanya. Pemerintah hanya memproduksi nilai ekonomis terhadap kebudayaan yang sebenarnya telah dibentuk oleh komunitas sebagai identitasnya melalui kesenian, ritual, dan berbagai simbol-simbol. Komodifikasi kebudayaan tidak hanya sebagai proses perdagangan kebudayaan, melainkan sebuah pengalihan dan manipulasi hasil-hasil pikiran komunitas menjadi komoditas. Hal ini mengindikasikan sebuah kebudayaan yang dalam identitas komunitas yang dimunculkan kembali tidak serta merta sama persis, bahkan terkait dengan konsep nilai kapitalistik yang pada akhirnya memunculkan komodifikasi.

\section{Hubungan Motif Melaksanakan Upacara Tradisional Seren Taun dengan Perilaku Melaksanakan Upacara Tradisional Seren Taun Warga Kampung Budaya Sindangbarang dalam Pembentukan Identitas Komunitas}

Penyajian data dimulai dengan mendeskripsikan variabel yang akan diuji hubungan kausalnya. Deskripsi variabel motif melaksanakan upacara tradisional Seren Taun bertujuan untuk memberikan gambaran tentang motif dan perilaku melaksanakan upacara tradisional Seren Taun warga Kampung Budaya Sindangbarang. Setelah setiap variabel yang akan diuji dideskripsikan, maka penyajian data berikutnya adalah penjelasan mengenai hubungan antara motif melaksanakan upacara tradisional Seren Taun dengan perilaku melaksanakan upacara tradisional dalam pembentukan identitas komunitas.

Secara umum perilaku melaksanakan upacara tradisional Seren Taun warga Kampung Budaya Sindangbarang cukup tinggi, yaitu sebesar 43,3 persen dan pada tingkatan sedang yaitu sebesar 53,3 persen (Tabel 10). Angka ini menunjukan bahwa ketika melaksanakan upacara tradisional Seren Taun, tiap individu Kampung Budaya Sindangbarang memiliki perilaku yang tinggi. Warga Kampung Budaya Sindangbarang relatif memiliki kecenderungan yang tinggi pada aktivitas dan keikutsertaan dalam pelaksanaan upacara tradisional Seren Taun.

Tabel 10. Jumlah dan Persentase Pelaku Upacara Seren Taun menurut Perilaku Melaksanakan Upacara Seren Taun

\begin{tabular}{|l|r|r|}
\hline \multicolumn{1}{|c|}{$\begin{array}{c}\text { Perilaku Melaksanakan Upacara } \\
\text { Seren Taun }\end{array}$} & Frekuensi (orang) & Persentase (\%) \\
\hline Rendah & 1 & 3,3 \\
\hline Sedang & 16 & 53,3 \\
\hline Tinggi & 13 & 43,3 \\
\hline Total & 30 & 100,0 \\
\hline
\end{tabular}

Perilaku yang ditunjukan oleh warga Kampung Budaya Sindangbarang meliputi aktivitas-aktivitas yang berkenaan dengan segala kegiatan yang dimulai dari persiapan prosesi upacara Seren Taun hingga prosesi 
penutupan upacara Seren Taun. Perilaku warga Kampung Budaya Sindangbarang yang dapat dilihat sebagai perilaku yang mendukung pelaksanaan upacara tradisional Seren Taun, yaitu diantaranya dapat dilihat dalam kegiatan ngajayak, penumbukan padi, dan membawa hasil bumi dari empat penjuru. Dengan melihat kegiatan-kegiatan tersebut pun maka dapat diketahui seberapa besar kepedulian warga Kampung Budaya Sindangbarang akan upacara tradisional Seren Taun untuk mengekspresikan identitasnya.

Pada tahap awal kegiatan upacara Seren Taun, prosesi ngajayak atau yang dikenal dengan tahapan menyambut atau menjemput padi merupakan tahapan yang paling awal dilakukan oleh warga Kampung Budaya Sindangbarang. Dimungkinkan dalam tahap ngajayak semua warga, baik yang terlibat langsung maupun yang hanya terlibat dalam tahap persiapan saja, ikut serta untuk mengikuti iring-iringan peserta upacara menuju lapangan upacara. Sebagaimana pengakuan Bapak Ukat sebagai koordinator upacara, sebagai berikut:

“...arak-arakan upacara berjalan
perlahan-lahan menuju lapangan
upacara diiringi tetabuhan dari macem-
macem kesenian tradisional. Di
sepanjang kiri-kanan jalan menuju
tempat upacara penuh berdesakan
warga masyarakat setempat. Dari luar
daerah pun banyak yang datang untuk
melihat jalannya upacara".

Tabel 10 memperlihatkan secara umum warga Kampung Budaya Sindangbarang ikut serta dan berperan aktif dalam kesenian tradisional Sunda yang ditampilkan dalam upacara tradisional Seren Taun. Kesenian tradisional Sunda yang ditampilkan dalam upacara tradisional tersebut diantaranya adalah damar sewu, tari buyung, pesta dadung, ngamamerokeun, tarawangsa, dan seribu kentongan. Pada kesenian tradisional Sunda, damar sewu, dimungkinkan warga Kampung Budaya Sindangbarang yang mengikuti prosesi upacara Seren Taun akan ikut serta dan berperan aktif. Hal tersebut disebabkan kesenian damar sewu merupakan helaran budaya yang mengawali rangkaian upacara Seren Taun yang menggambarkan manusia dalam menjalani proses kehidupan baik secara pribadi dan sosial. Alasan lain mengapa pada kesenian damar sewu ini dimungkinkan keikutsertaan para warga Kampung Budaya Sindangbarang, disebabkan pada kesenian ini merupakan tahap pembagian makanan dan berbagai sesajen yang dipercaya membawa keberkahan. Sebagaimana penjelasan oleh Bapak Aseng yang dikutip sebagai berikut:
“....ada yang disebut damar sewu, ini waktunya upacara Seren Taun diisi dengan doa-doa yang dipimpin oleh ustad. Selanjutnya diiringi dengan permainan berbagai alat musik tradisional dan ngebagiin makanan yang ada di dalam jampana-jampana dan kenceh-kenceh untuk masyarakat yang ada di tengah lapangan yang hadir di prosesi upacara Seren Taun".

Kesenian tradisional yang ditampilkan dalam upacara tradisional Seren Taun secara umum memiliki makna bahwa pola hidup manusia haruslah seimbang dengan alamnya. Makna tersebut dicerminkan melalui simbolsimbol dalam bunyi-bunyian dan tarian-tarian. Seperti halnya dalam tarian buyung hingga seribu kentongan yang diikuti oleh warga Kampung Budaya Sindangbarang. Hal ini lah yang menjadikan alasan betapa besarnya atau tingginya perilaku warga Kampung Budaya Sindangbarang dalam melaksanakan upacara tradisional Seren Taun.

Hipotesis awal menyatakan bahwa semakin rendah motif melaksanakan upacara tradisional Seren Taun maka akan semakin rendah perilaku melaksanakan upacara tradisional Seren Taun, maupun semakin tinggi motif melaksanakan upacara tradisional Seren Taun maka akan semakin tinggi perilaku melaksanakan upacara tradisional Seren Taun. Agar dapat melihat hubungan keduanya, maka dilakukan uji hubungan dengan menggunakan tabulasi silang dan analisis pearson's. Pengambilan keputusan berdasarkan nilai signifikansi (Approx. Sig.), jika Approx. Sig. lebih besar dari $\alpha(0,05)$ maka Ho diterima, artinya tidak terdapat hubungan antara variabel-variabel yang diuji.

Tabel 11. Persentase Pelaku Upacara Seren Taun menurut Motif Melaksanakan Upacara Seren Taun dan Perilaku Melaksanakan Upacara Seren Taun

\begin{tabular}{|l|r|r|r|}
\hline \multirow{2}{*}{$\begin{array}{c}\text { Perilaku Melaksanakan Upacara } \\
\text { Seren Taum }\end{array}$} & \multicolumn{4}{|c|}{$\begin{array}{c}\text { Motif Melaksanakan Upacara } \\
\text { Seren Taun (\%) }\end{array}$} \\
\cline { 2 - 4 } & \multicolumn{1}{|c|}{ Rendah } & \multicolumn{1}{c|}{ Sedang } & \multicolumn{1}{c|}{ Tinggi } \\
\hline Rendah & 50,0 & 0 & 0 \\
\hline Sedang & 50,0 & 50,0 & 7,7 \\
\hline Tinggi & 0 & 50,0 & 92,3 \\
\hline Total & 100,0 & 100,0 & 100,0 \\
\hline
\end{tabular}

Sebelumnya telah diuraikan bahwa perilaku melaksanakan upacara tradisional Seren Taun, warga Kampung Budaya Sindangbarang secara umum relatif tinggi. Hal ini disebabkan adanya sesuatu yang melatarbelakangi dan alasan yang kuat sehingga warga Kampung Budaya Sindangbarang ikut serta dan berperan aktif dalam upacara tradisional Seren Taun. Sehingga tidak dapat dipungkiri apabila tiap aktivitas atau kegiatan yang diikuti oleh warga Kampung Budaya Sindangbarang dalam melaksanakan upacara tradisional Seren Taun cenderung dihubungkan dengan motif melaksanakan upacara tradisional Seren Taun.

Tabel 11 menunjukan bahwa 92,3 persen warga Kampung Budaya Sindangbarang yang memiliki kecenderungan yang tinggi terhadap motif melaksanakan upacara tradisional Seren Taun. Dalam Tabel 11 secara umum terlihat bahwa semakin tinggi motif melaksanakan upacara tradisional Seren Taun maka semakin tinggi perilaku melaksanakan upacara tradisional Seren Taun. Hal tersebut berarti ada hubungan antara motif melaksanakan upacara tradisional Seren Taun dengan perilaku melaksanakan upacara tradisional Seren Taun, yaitu semakin tinggi motif melaksanakan upacara tradisional Seren Taun maka semakin tinggi perilaku melaksanakan upacara tradisional Seren Taun.

190 | Prasetyo, Untung. et. al. Komodifikasi Upacara Tradisional Seren Taun dalam Pembentukan Identitas Komunitas 
Pada perilaku melaksanakan upacara tradisional Seren Taun peneliti mencoba melihat keikusertaan warga Kampung Budaya Sindangbarang melalui berperan aktifnya warga Kampung Budaya Sindangbarang dalam tahapan ngajayak, penumbukan padi, membawa hasil bumi dari 4 penjuru, kesenian damar sewu, tari buyung, pesta dadung, ngamamerokeun, tarawangsa, dan seribu kentongan. Selain itu, peneliti pun mencoba berwawancara dengan warga Kampung Budaya Sindangbarang apakah dan mengapa mereka secara sukarela ikut serta dan berperan aktif dalam melaksanakan upacara tradisional Seren Taun. Sehingga pada selanjutnya akan diketaui bahwa perilaku melaksanakan upacara tradisional Seren Taun merupakan tindakan nyata dari motif melaksanakan upacara tradisional Seren Taun.

\section{Tabel 12. Persentase Pelaku Upacara Seren Taun menunut Motif Rasa Syukur pada Yang Maha Kuasa dan Perilaku Melaksanakan Upacara Seren Taun.}

\begin{tabular}{|l|r|r|r|}
\hline \multirow{2}{*}{$\begin{array}{c}\text { Perilaku Melaksanakan Upacara } \\
\text { Seren Taun }\end{array}$} & \multicolumn{3}{|c|}{$\begin{array}{c}\text { Motif Rasa Syukur pada Yang Maha } \\
\text { Kuasa (\%) }\end{array}$} \\
\cline { 2 - 4 } & \multicolumn{1}{|c|}{ Rendah } & \multicolumn{1}{c|}{ Sedang } & \multicolumn{1}{c|}{ Tinggi } \\
\hline Rendah & 100,0 & 0 & 0 \\
\hline Sedang & 0 & 0 & 13,8 \\
\hline Tinggi & 0 & 0 & 86,2 \\
\hline Total & 100,0 & 0 & 100,0 \\
\hline
\end{tabular}

Tabel 12 memperlihatkan sebesar 86,2 persen perilaku warga Kampung Budaya Sindangbarang cukup tinggi dalam melaksanakan upacara tradisional Seren Taun dan sebesar 13,8 persen dalam kategori sedang dengan kategori motif melaksanakan upacara tradisional Seren Taun yang tinggi. Hal tersebut menjelaskan bahwa warga Kampung Budaya Sindangbarang telah berperan aktif dalam prosesi ngajayak bukan karena tanpa alasan. Melainkan warga Kampung Budaya Sindangbarang percaya bahwa pada saat prosesi ngajayak merupakan prosesi untuk mendapatkan keberkahan. Hal tersebut sesuai dengan motif warga Kampung budaya Sindangbarang dalam melaksanakan upacara tradisional Seren Taun, yaitu harapannya untuk mendapatkan rezeki dan perlindungan dari Tuhan Yang Maha Kuasa serta keberkahan pada waktu yang akan datang.

Tabel 13. Persentase Pelaku Upacara Seren Taun menurut Motif Pelestarian Kelembagaan Komunitas dan Perilaku Melaksanakan Upacara Seren Taun.

\begin{tabular}{|l|r|r|r|}
\hline \multirow{2}{*}{$\begin{array}{c}\text { Perilaku Melaksanakan Upacara } \\
\text { Seren Taun }\end{array}$} & \multicolumn{4}{|c|}{$\begin{array}{c}\text { Motif Pelestarian Kelembagaan } \\
\text { Komunitas (\%) }\end{array}$} \\
\cline { 2 - 4 } & \multicolumn{1}{|c|}{ Rendah } & \multicolumn{1}{c|}{ Sedang } & \multicolumn{1}{c|}{ Tinggi } \\
\hline Rendah & 100,0 & 0 & 0 \\
\hline Sedang & 0 & 0 & 13,8 \\
\hline Tinggi & 0 & 0 & 86,2 \\
\hline Total & 100,0 & 0 & 100,0 \\
\hline
\end{tabular}

Tabel 13 menjelaskan bahwa perilaku melaksanakan upacara tradisional Seren Taun merupakan rekonstruksi kehidupan manusia yang mematuhi adat istiadat yang berlaku dalam komunitas Kampung Budaya Sindangbarang yang mengikat perorangan atau kelompok. Diketahui bahwa fungsi adat istiadat adalah sebagai pengatur, penata, dan pemelihara ketertiban masyarakat. Kewenangan pengaturan, penataan dan pemeliharaan ketertiban masyarakat ini diakui oleh warga. Beradasarkan hal tersebut, upacara tradisional Seren Taun sangatlah mudah untuk dilaksanakan oleh warga Kampung Budaya Sindangbarang karena upacara tradisional Seren Taun ditata dan diatur oleh aturan yang merupakan warisan budaya nenek moyang daerah Sindangbarang. Peraturan tersebut adalah religi, yaitu agama islam. Sebagaimana pendapat salah satu panggiwa Kampung Budaya Sindangbarang, sebagai berikut:

“...prinsipnya, upacara Seren Taun
bukan untuk memuja, apalagi
menduakan Allah SWT, melainkan
untuk melestarikan nilai-nilai budaya
nenek moyang. Masyarakat Kampung
Budaya Sindangbarang, mayoritas
memeluk agama islam”.

Sama halnya dengan prosesi ngajayak, prosesi-prosesi lainnya pun mempunyai makna yang sejalan dengan motif warga Kampung Budaya Sindangbarang dalam melaksanakan upacara tradisional. Sebagai contoh, penumbukan padi dan membawa hasil bumi dari 4 penjuru yang selanjutnya dimasukan ke dalam leuit memiliki makna bahwa manusia harus dapat menyisihkan padi atau hasil bumi lainnya untuk disimpan sebagai tabungan agar hidup tidak kekurangan. Hal tersebut sesuai dengan motif melaksanakan upacara tradisional Seren Taun, yaitu bertujuan untuk memohon kepada Tuhan Yang Maha Kuasa agar terhindar dari kekurangan, baik pangan, sandang, maupun papan.

Tabel 14. Persentase Pelaku Upacara Seren Taun menurut Motif Pelestarian Kesenian Tradisional dan Perilaku Melaksanakan Upacara Seren Taun.

\begin{tabular}{|c|c|c|c|}
\hline \multirow[t]{2}{*}{$\begin{array}{c}\text { Perilaku Melaksanakan Upacara } \\
\text { Seren Taun }\end{array}$} & \multicolumn{3}{|c|}{$\begin{array}{l}\text { Motif Pelestarian Kesenian } \\
\text { Tradisional (\%) }\end{array}$} \\
\hline & Rendah & Sedang & Tinggi \\
\hline Rendah & 0 & 0 & 3,4 \\
\hline Sedang & 100,0 & 0 & 10,4 \\
\hline Tinggi & 0 & 0 & 86,2 \\
\hline Total & 100,0 & 0 & 100,0 \\
\hline
\end{tabular}

Tabel 14 menjelaskan bahwa motif melestarikan kesenian tradisional Sunda pada warga Kampung Budaya Sindangbarang cukup tinggi yaitu sebesar 86,2 persen. Hal ini menjelaskan bahwa perilaku melestarikan kesenian tradisional Seren Taun pun cukup tinggi. Kesenian yang ditampilkan dalam upacara tradisional Seren Taun pada hakikatnya memiliki makna dan tujuan yang berbeda. Menurut Bapak Aseng dalam sesi wawancara, dijelaskan bahwa kesenian dalam upacara tradisional memiliki makna yang sangat sakral, yaitu kesenian nenek moyang yang lagu-lagunya sarat nilai-nilai kehidupan, pepatah atau petuah dalam menjalani kehidupan. Tujuan ditampilkannya kesenian tradisional dalam upacara Seren Taun selain sebagai pengiring prosesi upacara, kesenian tersebut juga 
ditujukan untuk menghidupkan, memperkenalkan, dan melestarikan kesenian tradisional Sunda kepada remaja Kampung Budaya Sindangbarang dan Desa Pasireurih serta kepada khalayak publik yang menghadiri upacara tersebut. Hal tersebut mengindikasikan adanya hubungan antara motif dengan perilaku melaksanakan upacara tradisional Seren Taun dalam hal melestarikan kesenian tradisional Seren Taun.

\section{Hubungan Komodifikasi Upacara Tradisional Seren Taun dengan Pembentukan Identitas Komunitas Kampung Budaya Sindangbarang}

Melihat kembali pada subbab sebelumnya bahwa menurut Surbakti (2009) melihat komodifikasi sebagai suatu proses yang menjadikan suatu hasil kebudayaan menjadi komoditas dengan pengubahan dan pengemasan ulang melalui perubahan-perubahan yang dilakukan terhadap unsur kebudayaan itu sendiri. Selanjutnya Surbakti (2009) menjelaskan bahwa komodifikasi merupakan proses yang berjalan disebabkan adanya kombinasi kekuatan antara pemerintah dan pengusaha. Dalam beberapa penelitian ditemukan bahwa komodifikasi kebudayaan memiliki implikasi buruk terhadap kebudayaan itu sendiri, dimulai berubahnya estetika komunitas, meluruhnya sejarah terbentuknya komunitas, hingga identitas komunitas menjadi kabur.

Berdasarkan hal tersebut, Utama (2009) menunjukan fakta bahwa "nilai tinggi" kebudayaan lebih ditujukan karena nilai ekonomisnya, yaitu nilai rupiah atau harga jualnya. Hal tersebut mengindikasikan bahwa pemberian penghargaan atas status kebudayaan sebagai kebudayaan yang bernilai tinggi pun lalu berfungsi sebagai semacam iklan yang dapat mendatangkan keuntungan. Hal tersebut dapat dilihat dari peningkatan jumlah wisatawan, pameran kebudayaan, publikasi kebudayaan melalui media massa, dan banyaknya pengunjung lebih dipentingkan.

Komodifikasi kebudayaan tidak hanya sebagai proses perdagangan kebudayaan, melainkan sebuah pengalihan dan manipulasi hasil-hasil pikiran komunitas menjadi komoditas. Hal ini mengindikasikan sebuah kebudayaan yang dalam identitas komunitas yang dimunculkan kembali tidak sama seperti di awal kemunculannya, bahkan terkait dengan konsep kapitalistik yang pada akhirnya memunculkan komodifikasi. Berdasarkan realitas sosial yang terjadi terlihat bahwa pemerintah hanya memproduksi nilai ekonomis terhadap kebudayaan yang sebenarnya telah dibentuk oleh komunitas sebagai identitasnya melalui kesenian, ritual, dan berbagai simbol-simbol. Implikasi yang muncul dalam kehidupan komunitas adalah identitas sebagai karakteristik komunitas terus menerus luruh, dan yang tampil di permukaan adalah perasaan bahwa mereka warga dari suatu komunitas yang sama.

Luruhnya identitas komunitas disebabkan karena adanya ekspansi pasar, pengaruh etos kerja kapitalistik, dan masyarakat yang berorientasi pada pasar (transaksi) dimana tidak hanya mempengaruhi kehidupan suatu komunitas, tetapi juga mempengaruhi sistem nilai dan tata hubungan sosial (Utama, 2009). Di sisi lain komodifikasi kebudayaan pun merubah orientasi manusia dalam membentuk maupun ikut serta dalam sebuah komunitas, bukan hanya sebagai simbol solidaritas yang identik dalam komunitas, melainkan lebih didominasi oleh gaya hidup. Keikutsertaan dalam sebuah komunitas dengan orientasi gaya hidup dilatarbelakangi oleh usaha hidup dalam tampilan "diri" yang mengikuti pasar dimana komunitas bukan sebagai "rumah" tetapi sebagai "panggung" (Wicandra, 2006). Hal ini memperlihatkan bahwa komunitas tidak lagi dibangun dalam kerangka membentuk identitas dengan segala karakteristik kebudayaannya, melainkan dibentuk berdasarkan perkembangan pasar melalui komodifikasi kebudayaan.

Berdasarkan uraian di atas, komodifikasi secara nyata telah meluruhkan identitas komunitas. Namun hal tersebut tidak terjadi pada komodifikasi upacara tradisional Seren Taun Kampung Budaya Sindangbarang. Berdasarkan subbab 5.1, proses komodifikasi upacara tradisional Seren Taun cukup rendah untuk mempengaruhi motif melaksanakan upacara tradisional Seren Taun. Meskipun tidak dipungkiri pula bahwa proses komodifikasi lebih terasa pada aras pemerintah daerah, dalam hal ini pemerintah Desa Pasireurih dan Kabupaten Bogor. Pada aras kepemerintahan, upacara tradisional Seren Taun dipandang sebagai aset yang dapat menyejahterakan kehidupan sekitar dan menambah pendapatan daerah melalui kegiatan pariwisatanya. Sebagaimana dikutip dalam bogoronline.com (2006), Wakil Bupati Bogor, Albert Pribadi mengungkapkan bahwa:

“...dengan adanya Kampung Budaya
Sindangbarang dan upacara Seren
Taun ini, aset devisa Kabupaten Bogor
dalam bidang pariwisata akan
bertambah dengan melalui daya tarik
pariwisata kebudayaan dan seni Jawa
Barat-nya yang begitu kental dan masih
alami”.

Pada hipotesis awal dinyatakan bahwa semakin tinggi komodifikasi upacara tradisional Seren Taun maka akan semakin rendah motif melaksanakan upacara tradisional Seren Taun. Selanjutnya semakin rendahnya motif melaksanakan upacara tradisional Seren Taun maka akan semakin rendah perilaku melaksanakan upacara tradisional Seren Taun, dan semakin rendah perilaku melaksanakan upacara tradisional Seren Taun maka akan semakin lemahnya pembentukan identitas komunitas. Sedangkan pada hasil uji kuesioner dan hasil wawancara, diketahui bahwa yang terjadi adalah rendahnya komodifikasi upacara tradisional Seren Taun di Kampung Budaya Sindangbarang. Sehingga yang terjadi adalah tingginya motif dan perilaku melaksanakan upacara tradisional Seren Taun yang memberikan peluang menguatnya pembentukan identitas komunitas Kampung Budaya Sindangbarang.

Secara jelas Tabel 9 pada memperlihatkan bahwa proses komodifikasi memiliki hubungan yang signifikan tetapi tidak mempengaruhi motif melaksanakan upacara tradisional Seren Taun. Berdasarkan hal tersebut, dapat dijelaskan mengapa proses komodifikasi upacara 
tradisional Seren Taun tidak memiliki pengaruh terhadap pembentukan identitas komunitas?. Hal tersebut disebabkan 2 faktor yang melatarbelakangi terjaganya eksistensi upacara tradisional Seren Taun, yaitu tingginya motif warga Kampung Budaya Sindangbarang dalam melaksanakan upacara tradisional Seren Taun dan kuatnya aspek-aspek pranata yang mengatur upacara tradisional Seren Taun tersebut.

Pada subbab 5 telah dijelaskan hubungan komodifikasi upacara tradisional Seren Taun dengan motif melaksanakan upacara tradisional Seren Taun. Selanjutnya peneliti ingin menjelaskan aspek-aspek pranata yang mengatur upacara tradisional Seren Taun sehingga proses komodifikasi upacara tradisional Seren Taun tidak mempengaruhi pembentukan identitas komunitas. Pada beberapa teori Komunikasi dan Manajemen Lintas Budaya dijelaskan bahwa unsurunsur kebudayaan memiliki aspek-aspek pranatanya, yaitu kebutuhan kehidupan kekerabatan, pencarian hidup, ilmiah manusia, rasa keindahan (rekreasi), berhubungan dengan Tuhan, dan kebutuhan jasmaniah.

Dalam upacara tradisional Seren Taun diketahui terdapat motif pelestarian kelembagaan komunitas. Dalam motif tersebut didalamnya ditemukan alasanalasan dalam melaksanakan upacara tradisional Seren Taun adalah untuk mempererat ikatan sosial antar warga atau kekerabatan warga Kampung Budaya Sindangbarang. Sejalan dengan pranata tersebut, salah satu kokolot yaitu Bapak Ukat, menegaskan bahwa:

\section{“...keturunan pendahulu Kampung Budaya Sindangbarang harus bersatu dan dalam satu ikatan keluarga, cuman Seren Taun yang bisa mempersatukan kekerabatan keluarga di Kampung Budaya Sindangbarang”.}

Pelaksanaan upacara tradisional Seren Taun memberikan tokoh panutan atau sosok yang harus dihormati bagi warga Kampung Budaya Sindangbarang dalam pencarian hidupnya. Dalam upacara tradisional Seren Taun terdapat sosok Nyi Pohaci atau Nyi Sri Rumbiyang Jati yang diasosiasikan dengan dewi kesuburan. Dewi kesuburan inilah yang menjadi kepercayaan warga Kampung Budaya Sindangbarang dalam memberikan kelimpahan hasil panen di Sindangbarang. Apabila tidak atau kurang sakral dalam melaksanakan upacara tradisional Seren Taun, maka dipercaya akan terjadi bencana atau suatu bahaya yang melanda lahan pertanian Sindangbarang. Sebagaimana dikutip dalam wawancara dengan Bapak Ukat, yaitu "sesajen harus lengkap, jika tidak, menandakan kurangnya rasa hormat dan terima kasih kepada Dewi Sri". Pranata inilah yang membuat warga Kampung Budaya Sindangbarang tetap menjalankan upacara tradisional Seren Taun sesuai dengan tuntunan leluhurnya.

Pada hakikatnya upacara tradisional Seren Taun adalah acara penyerahan hasil bumi berupa padi yang dihasilkan dalam kurun waktu satu tahun, untuk disimpan ke dalam lumbung (leuit). Upacara tradisional Seren Taun merupakan bentuk nyata warga Kampung
Budaya Sindangbarang bahwa manusia berpikir ilmiah. Warga Kampung Budaya Sindangbarang percaya bahwa dengan melaksanakan upacara tradisional Seren Taun maka warga Kampung Budaya Sindangbarang telah mempersiapkan "tabungan" berupa bahan pangan (padi) yang dapat digunakan pada waktu-waktu mendatang agar tidak terjadi kekurangan ataupun kelaparan. Berdasarkan pemikiran itulah maka tidak ada alasan bagi warga Kampung Budaya Sindangbarang untuk menolak melaksanakan upacara tradisional Seren Taun.

Pada pranata rasa keindahan (rekreasi) dan kebutuhan jasmaniah, upacara tradisional Seren Taun memenuhi kebutuhan manusia dalam bentuk kesenian tradisional Sunda. Selain sebagai upacara sakral yang secara rutin dilaksanakan di Kampung Budaya Sindangbarang, Seren Taun memiliki makna tersendiri bagi warga Kampung Budaya Sindangbarang, yaitu sebagai upaya memenuhi kebutuhan warga Kampung Budaya Sindangbarang dalam hal kesenian tradisional. Pergelaran kesenian tradisional Sunda dalam upacara tradisional Seren Taun memberikan gambaran bahwa kebudayaan merupakan aspek penting dalam menjaga eksistensi identitas komunitasnya. Sebagaimana dikutip dalam bogoronline.com (2006), Bapak Maki berpesan kepada masyarakat Kampung Budaya Sindangbarang agar lebih peduli dengan adat dan budaya Sunda di Bogor yang memiliki ke-khas-an sendiri. Budayawan Anis DjatiSunda mengatakan bahwa Seren Taun yang diadakan di Kampung Budaya Sindangbarang merupakan bentuk ikatan emosional warga setempat terhadap tradisi dan budaya Sunda yang ada.

Pranata kebudayaan selanjutnya, yaitu berhubungan dengan Tuhan. Warga Kampung Budaya Sindangbarang percaya bahwa hidup ada yang mengaturnya, yaitu Allah SWT. Sebagaimana ungkapan dalam bahasa Sunda, yaitu usik diusikuen malik dimalikeun kersaning Gusti Maha Suci. Maksudnya adalah agar hidup tidak serba kekurangan maka harus selalu ingat kepada sang Pencipta dengan jalan beribadah, berdoa, menjalankan perintah-Nya serta menjauhi larangan-Nya. Upacara tradisional merupakan pengaktualisasian warga Kampung Budaya Sindangbarang untuk berhubungan dengan Tuhan-nya. Upacara tradisional Seren Taun di Kampung Budaya Sindangbarang telah direkonstruksi dan direvitalisasi dengan bimbingan dan petunjuk sesepuh dan kokolot menjadikan warga Kampung Budaya Sindangbarang tidak kehilangan jati dirinya sebagai orang Sunda dalam komunitas Kampung Budaya Sindangbarang.

\section{KESIMPULAN DAN SARAN}

\section{Kesimpulan}

Upacara tradisional Seren Taun adalah ungkapan syukur dan do'a masyarakat Sunda atas suka duka yang mereka alami terutama di bidang pertanian selama setahun yang telah berlalu dan tahun yang akan datang yang dilaksanakan setiap tanggal 22 Bulan Rayagung (bulan terakhir dalam perhitungan kalender Sunda) yang didalamnya selain terdapat ritual-ritual yang bersifat sakral, digelar juga kesenian dan hiburan. Seperti di 
Kampung Budaya Sindangbarang, dan juga di kampung adat lainnya, melaksanakan upacara Seren Taun dimaksudkan sebagai ungkapan rasa syukur. Melalui upacara tradisional Seren Taun ini masyarakat dapat ikut berperan aktif sehingga tercipta ikatan sosial yang lebih kokoh. Sebagaimana tercermin dari pola kehidupan masyarakat Sunda yang komunal, silih asah, silih asih, dan silih asuh. Namun demikian, upacara Seren Taun yang dilaksanakan oleh warga Kampung Budaya Sindangbarang dalam beberapa hal dapat dikatakan sedikit berbeda. Pemilihan waktu pelaksanaan yaitu pada bulan Muharram, mungkin dapat ditemui pada beberapa kampung adat yang lain. Tetapi penambahan tersebut (mengambil air dari tujuh mata air, pengajian, dan sunatan massal) adalah cara lain yang diharapkan dapat lebih meningkatkan ikatan sosial dan kepedulian diantara warga Kampung Budaya Sindangbarang.

Hubungan antara komodifikasi upacara tradisional Seren Taun dengan pembentukan identitas komunitas Kampung Budaya Sindangbarang menunjukan hubungan yang signifikan. Semakin rendah proses komodifikasi upacara tradisional Seren Taun maka semakin kuat pembentukan identitas komunitas Kampung Budaya Sindangbarang. Hal ini dapat dijelaskan karena terdapat hubungan yang signifikan pula antara komodifikasi upacara tradisional Seren Taun dengan motif dan perilaku melaksanakan upacara tradisional Seren Taun.

Diketahui bahwa proses komodifikasi upacara tradisional Seren Taun Kampung Budaya Sindangbarang cenderung rendah, sehingga motif dan perilaku melaksanakan upacara tradisional Seren Taun cenderung tinggi. Hal ini disebabkan warga Kampung Budaya Sindangbarang tetap memandang upacara tradisional Seren Taun sebagai fasilitas mereka untuk mengekspresikan rasa syukur kepada Tuhan YME dan dewi kesuburan, membina solidaritas dan kekerabatan antar warga, melestarikan kelembagaan komunitas, dan melestarikan kesenian tradisional Sunda. Walaupun tidak dipungkiri bahwa pemerintah daerah pun memiliki tujuan tersendiri dengan adanya upacara tradisional Seren Taun. Tujuan tersebut yaitu mengagendakan upacara Seren Taun sebagai objek wisata budaya sehingga menjadikan Desa Pasireurih lebih dikenal dan kondusif untuk meningkatkan pembangunan.

\section{Saran}

Upacara tradisional Seren Taun mencerminkan karakteristik masyarakat Kampung Budaya Sindangbarang, Desa Pasireurih yang penuh kekeluargaan dan dedikasi yang tinggi antarsesama warga masyarakat. Upacara tradisional Seren Taun juga mampu mengeliminasi kesenjangan status sosial warga masyarakat dalam struktur stratifikasi sosial di tempat tersebut. Upacara tradisional Seren Taun merupakan upaya untuk mengangkat kembali kekayaan budaya tradisional Sunda.

Hal lain, terlepas dari apapun upaya masyarakat Kampung Budaya Sindangbarang melaksanakan upacara tradisional Seren Taun yang bersifat sakral memang memerlukan sumber-sumber data yang akurat. Namun, akurasi data bukan satu-satunya sebagai alasan mengapa masyarakat Kampung Budaya Sindangbarang melaksanakan upacara tradisional Seren Taun. Melainkan para pelaku kegiatan tersebut sendiri menduduki peran yang sentral. Menurut orang luar Kampung Budaya Sindangbarang, upacara tradisional dianggap bukan merupakan upacara adat atau ritual keagamaan. Namun sebaliknya bagaimana jika para pelaku itu sendiri mempercayai dan meyakini sepenuhnya bahwa dengan melakukan kegiatan tersebut mendatangkan ketenangan ataupun keberkahan. Inilah bukti bahwa masyarakat Kampung Budaya Sindangbarang yang melaksanakan upacara tradisional Seren Taun merupakan gambaran masyarakat komunal yang tidak lupa terhadap adat istiadat leluhur sebagai identitas komunitasnya.

Selain itu, di dalamnya juga terdapat unsur gotong royong yang merupakan ciri khas masyarakat Indonesia, sekaligus dapat dijadikan modal untuk menyatukan warga. Adapun hal yang lebih hakiki, yaitu dalam pelaksanaan upacara tradisional Seren Taun terjadi proses transformasi nilai-nilai yang bisa dijadikan pegangan dan pedoman dalam hidup bermasyarakat. Berdasarkan uraian tersebut dan mengingat saratnya nilai-nilai yang terkandung dalam upacara tradisional Seren Taun, maka upacara tradisional Seren Taun harus dilestarikan dan direvitalisasi dengan beberapa cara, yaitu 1) membatasi pihak-pihak yang ikut serta dalam pelaksanaan upacara tradisional Seren Taun untuk menjaga kesakralanan dari makna upacara tersebut, 2) membatasi ikut campur pemerintah dalam penyelenggaraan upacara tradisional Seren Taun, 3) adanya pembelajaran kepada para pengunjung Kampung Budaya Sindangbarang akan makna-makna dalam upacara tradisional Seren Taun.

\section{DAFTAR PUSTAKA}

Alo, Liliweri. 2002. Dasar-dasar Komunikasi Antarbudaya. Pustaka Pelajar Offset. Yogyakarta.

Banindro, Baskoro Suryo. 2007. Gaya Psychedelia Counter Culture Amerika Komodifikasi Indonesia. Skripsi. Desain Komunikasi Visual. Fakultas Seni Rupa. Institut Seni Indonesia Yogyakarta.

Effendy, Bisri dan Anoegrajekti, Novi. 2004. Perempuan dalam Ritual. Mengangan Dewi Sri Membayang Perempuan: Studi Kasus Upacara Tradisional Seblang Masyarakat Using Banyuwangi. Srinthil. Jakarta.

Intani, Ria dan Andayani, Ria S. 2006. Upacara Tradisional Seren Taun. Dinas Kebudayaan dan Pariwisata Kabupaten Bogor. Bogor.

Ritzer, George dan Goodman, Douglas J. 2008. Teori Sosiologi (Edisi Terbaru). Kreasi Wacana. Yogyakarta. 
Rostiyati, Ani dan Susilantini, Endah. 1995. Fungsi Upacara Tradisional bagi Masyarakat Pendukungnya Masa Kini (Studi Kasus: Masyarakat Gadingharjo dan Pringgokusuma, Yogyakarta). Departemen Pendidikan dan Kebudayaan Daerah Istimewa Yogyakarta. Yogyakarta.

Singarimbun, Masri dan Effendi, Sofian. 1995. Metode Penelitian Survei. LP3ES. Jakarta.

Soekanto, Soerjono. 1982. Sosiologi Suatu Pengantar (Edisi Baru Kesatu). Perubahan-perubahan Sosial dan Kebudayaan. CV. Rajawali. Jakarta.

Surbakti, Asmyta. 2009. Sebuah Kajian Budaya: Pusaka Budaya dan Pengembangan Pariwisata di Kota Medan. Program Pasca Sarjana Universitas Udayana.

Utama, Mahendra P. 2009. Globalisasi, Diplomasi Kebudayaan, dan Komodifikasi Budaya. Skripsi. Jurusan Sejarah. Fakultas Ilmu Budaya. Universitas Diponegoro.

Wicandra, Bima. 2006. Graffiti di Indonesia: Sebuah Politik Identitas Ataukah Tren? (Kajian Politik Identitas pada Bomber di Surabaya). Skripsi. Jurusan Desain Komunikasi Visual. Fakultas Seni dan Desain. Universitas Kristen Petra Surabaya. 
196 | Prasetyo, Untung. et. al. Komodifikasi Upacara Tradisional Seren Taun dalam Pembentukan Identitas Komunitas 